\title{
İftirâk Hadisinin Yaygın Olmayan Bir Versiyonuna İliş̧in Bir İnceleme
}

\author{
A Review of an Unfamous Version of the Division Hadith \\ Bayram ÇINAR \\ Dr., Milli Eğitim Bakanlığı, Gazi Mesleki Eğitim Merkezi \\ Dr., Ministry of Education, Gazi Vocational Training Center \\ Ankara/TURKEY \\ kocacinarby@gmail.com \\ https://orcid.org/0000-0002-4886-7610 \\ Doi: $10.34085 /$ buifd. 983625
}

Öz

Ümmetin yetmiş üç fırkaya ayrılacağını ve bunlardan sadece birinin kurtuluşa ereceğini işaret eden iftirâk hadisi, İslam düşünce geleneğinde Mezheplerin oluşmasında ve şekillenmesinde belirleyici bir rol üstlenmiştir. Sahabe tabakasında oldukça zengin bir aktarım zeminine sahip bu rivayet, farklı söz kalıpları ile aktarılmıştır. Söz konusu rivayetin tüm metin farklılıkları bir yana, iki farklı mesajı içeren metinler olduğu tespit edilmiştir. Bu durumda; birinin doğru olduğu varsayıldığında diğeri mutlaka yanlış olmak zorundadır. Çünkü iki hadisin taşıdığı mesaj çelişiktir. Bu hadislerden biri oldukça yaygın bir networke sahiptir, bu yüzden bilinirliliği daha fazladır. Bu rivayet " biri hariç hepsi cehennemdedir" mesajı verir. Konuya ilişkin diğer hadis ise " biri hariç tümü cennettedir " mesajı aktarır. Bu ikinci hadisin çağrışımları daha pozitif olmasına karşın, İslam kültür geleneğinde daha az bilinmektedir. Çalışmamızda bu iki rivayetten daha pozitif çağrışımlı olanına yoğunlaşarak, İslam mezhepleri geleneğini bu hadis şekillendirmiş olsaydı nasıl bir tablo oluşurdu? gibi spekülatif bir çalışma yapılmıştır. Bu amaçla pozitif mesaj veren bu rivayetler ele alınarak incelenmiştir. Hadis otoritelerinin bunlara ilişkin yargıları da aktarılmıştır. Söz konusu iki hadis taşıdıkları mesajlar üzerinden bir değerlendirmeye tabi tutulmuştur. Sonuçta da bu çalışma, hadisin geleneğimizdeki söz konusu yeri göz önünde bulundurularak, mezhepleri nasıl şekillendirdiğini gösterme çabasında olunmuştur.

Anahtar Kelimeler: Kelâm, Mezheb, Fırka, İftirâk, İftirâk Hadisi.

\section{Abstract}

The division hadith, indicating that "the Ummah will be divided into seventy-three sects and only one of them will be saved", has played a decisive role in the formation of sects in the Islamic thought tradition. This narration, which has a very rich base of transmission regarding the Sahaba period, was conveyed with different narrators' phrases. Apart from all the text differences of the hadith in question, it has been determined that there are texts containing two different messages. In this case, assuming one is true, the other must be false. Because the message of the two hadiths is contradictory. One of these hadiths has a very common network, so it is more well known. This narration gives the message "All of them are in Hell, except one." The other hadith on the subject conveys the message "All of them are in Paradise, except one." Although the connotations of this second hadith are more positive, it is less known in the Islamic cultural tradition. If this hadith had shaped the tradition of Islamic sects by focusing on the more positively associated of these two narrations in our study, what kind of a picture would it have formed? such a speculative study has been conducted. For this purpose, this hadith, which gave a positive message, was taken and studied. The judgments of the hadith authorities regarding them were also cited. The two hadiths in question have been evaluated on the messages they carry. As a result, this study has made an effort to show how the hadith shaped the sects, considering its place in our tradition.

Keywords: Theology, Madhab, Sect, Division, al-Hadith of Iftiraq. 


\section{GİRIŞ}

İslam geleneği içerisinde fırkalaşmaya kaynaklık eden ve bu faaliyeti anlamlandırmaya imkân veren iftirâk hadisi, birbiri ile çelişen, iki ayrı yapıdan oluşur. Söz konusu rivayet grubu, içerdiği anlam itibarıyla iki farklı iddiaya kaynaklık eder. Bunlardan ilki;

"Ümmetim fırkaya ayrılacak, bunlardan biri hariç diğerlerinin tümü cennettedir" yargısı; Diğeri ise; "Ümmetim.................fırkaya ayrılacak, bunlardan biri hariç diğerlerinin tümü cehennemdedir." yargisı taşır.

Bu iki rivayet grubu, ifade ettikleri anlam itibarı ile çelişiktir. Dolayısıyla ikisinin aynı anda doğru olması olası değildir. Söz konusu rivayetlerden mesajı daha pozitif olan ilki, farklı sebeplerden dolayı yaygınlaşma imkânı bulamamışken, daha negatif mesaj veren ikinci yargıyı taşıyan rivayet, önemli oranda İslam mezhep geleneğinin kurucu metinlerinden biri kabul edilmiştir.

Çalışmamız bu iki rivayetten birinin yaygınlaşamamasının nedenlerini irdelemek ve şöhret bulmayan rivayetin; "şayet kurucu bir metin olsaydı" oluşacak yeni tabloyu varsaymak temelinde spekülatif bir arayış olacaktır. Konuya ilişkin çok sayıdaki çalışmada, objektifler şöhret bulan metinler topluluğuna odaklanmışken, biz kadrajımıza şöhret bul(a)mayan varyantı alacağız.

\section{1. İftirâk Hadisinin Meşhur Olmayan Versiyonu}

İftirâk hadisinin farklı iki versiyonundan biri; fırkalardan sadece birinin kurtuluşunu, diğerlerinin ise helak olacağı mesajı taşır. Buna karşın; diğer versiyonu ise söz konusu mezheplerden birinin helak olacağını, diğerlerinin ise hidayet üzere olduklarını dolayısıyla kurtulacakları mesajı taşır.

$\mathrm{Bu}$ algıya göre pozitif mesaj taşımasına rağmen alanda daha az bilineni, Enes $\mathrm{b}$. Malik'e dayandırılır. Bu versiyonu ç̧alışmamıza konu edilmiştir. Bu rivayete göre;

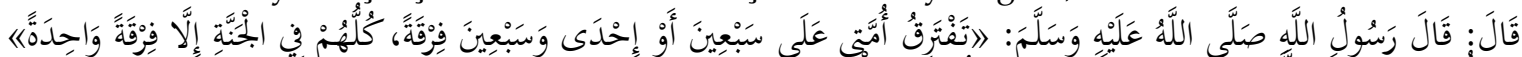

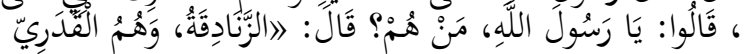

Resulullah "ümmetim yetmiş ya da yetmiş bir firkaya ayrılacak, bunlardan biri hariç diğgerlerinin tümü cennettedir" buyurdu. Denildi ki onlar kimlerdir Ey Allah'ın resulü: Buyurdular ki: "onlar Kaderiyye olan zenâdikâdır"1 Rivayete ilişkin olarak rical otoritelerinin kanaati, bu metnin Resulullah'a ait olmadığı dolayısıyla mevzu olduğu yönündedir. Söz konusu rivayeti uyduranın ise el-Ebred b. el-Eşres olduğudur. ${ }^{2}$ Rivayetin sıhhatine ilişkin bu yargının, onun gelenekte yaygınlaşmasını engelleyen önemli sebeplerden biri olduğu varsayılabilir.

Aynı mesajı taşıyan bir diğer rivayetin lafzı ise şöyledir:

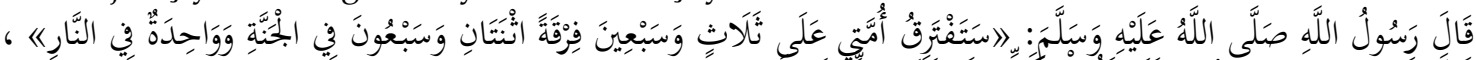

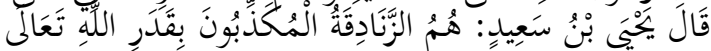

Resulullah "ümmetim yetmiş üç firkaya ayrllacak, bunlardan yetmiş iki firka cennette biri ise cehennemdedir" buyurdu. Hadis olarak aktarılan metinde olmayan, fakat ravillerden Yahya b. Saîd'in, Cehenneme gideceklere ilişkin olarak; "onlar Zenâdîkâ ve Allah'ın kaderini inkâr edenlerdir" şeklinde metne getirdiği yorum da rivayete yansımıştır. ${ }^{3}$ Yahya b. Saîd, cehenneme gidecekler kimlerdir diye Enes b. Malik'e sorduğunu, onun da "bana göre onlar zenâdîkâ ve Kaderiyye'dir" dediği aktarmıştır. ${ }^{4}$ Buna göre sözü edilen yorum, Yahya b. Saîd'e değil, Enes b. Malik'e aittir.

Yine Enes b. Malik'e isnat edilen ve aynı mesajı taşıyan bir başka rivayet ise şu lafızlarla aktarılmıştır:

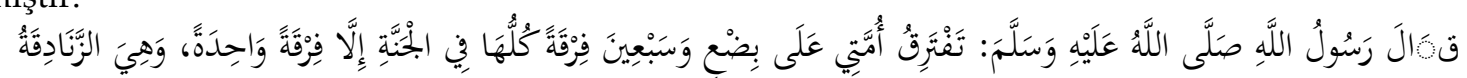

Resulullah"ümmetim yetmiş küsur firkaya ayrılacak, bunların biri hariç hepsi cennettedir. O bir tanesi de zenâdika'dır." buyurdu. ${ }^{5}$ Daha önce Enes b. Malik'e nispet edilen yorum, bu rivayette, metne dâhil edilmiş ve söz konusu tespitin Resulullah tarafında yapıldığı varsayılmıştır. Bu rivayete yapılan

\footnotetext{
1 Ebû Abdillâh Hüseyn b. İbrâhîm b. Hüseyn el-Hemedânî el-Cûzekānî/el-Cûrkânî, el-Ebâtil ve'l-Menâkîr ve's-Sihâh ve'l-Meşâhir thk. Abdulcebbâr Ferîvaî (Riyad: Dâru's-Samî'i, 2002), 1/ 459 (No. 277). Bu kitabın uydurma hadisleri senetleriyle birlikte kaydeden bir eser olduğu kaydedilmiştir. Bilgi için bk. Selman Başaran, "Cûzekânî”, Türkiye Diyanet Vakfi İslâm Ansiklopedisi (İstanbul: TDV Yayınları, 1993), 8/99.

2 Curkânî, el-Ebâtil ve'l-Menâkîr ve's-Sihâh ve'l-Meşâhir, 1/460, 461.

${ }^{3}$ Curkânî, el-Ebâtil ve'l-Menâkîr ve's-Sihâh ve'l-Meşâhir,1/461 (No. 278).

${ }^{4}$ Curkânî, el-Ebâtil ve'l-Menâkîr ve's-Sihâh ve'l-Meşâhir,1/462 (No. 279) .

${ }^{5}$ Curkânî, el-Ebâtil ve'l-Menâkîr ve's-Sihâh ve'l-Meşâhir,1/462 (No. 280).
} 
eleştiri, söz konusu rivayetin el-Ebred'den alındığı, lafzının ise sorunlu olduğu yönündedir. Buhârî gibi başka hadis otoriteleri ise özellikle rivayet senedinde yer alan Yâsîn $b$. Mu'az'a ilişkin eleştirilerde bulunmuşlardır. ${ }^{6}$

Aynı mesajı içeren bir başka rivayet ise;

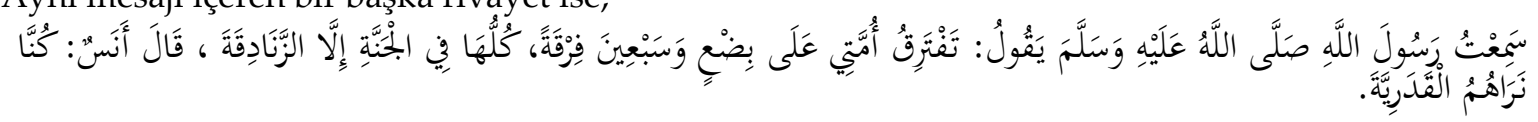

Resulullah'tan şöyle duydum "ümmetim yetmiş küsur fırkaya ayrılacak, bunların biri hariç hepsi cennettedir. Zenâdika bunun dışındadır" buyurdu. 7 Enes b. Malik, "biz onların Kaderiyye olduğunu düşünüyorduk" yorumuyla "zenâdîkâ" ya ilişkin kanaatini de rivayete ek olarak aktarmıştır. Bu rivayette, hadisin sahâbi tabakasındaki ismi olan Enes b. Malik, "semi'tu" diyerek aktarımın sihhatine dönük özel bir vurgu yapmasına karşın, söze konu rivayet el-Ebred $b$. el- Eşres'den kaynaklanan bir sebeple reddedilmiştir. Buna ek olarak rivayetin senedinde yer alan Osman b. Afvan el-Kuraşî sebebiyle de hadisin senedine itiraz edilir.

Kurgusu aynı, fakat mesajı benzerlerinden oldukça farklı bir rivayette ise

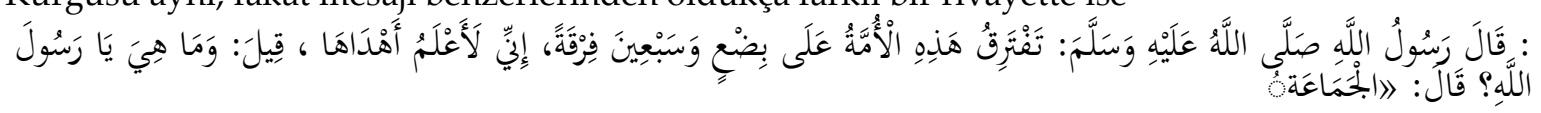

Resulullah " bu ümmet yetmiş küsur firkaya ayrllacak, onlardan hangisinin daha fazla hidayet üzere olacak olan bilmiyorum" diye buyurdu. Denildi ki o nedir Ey Allah'ın resulü, buyurdular ki O "cemâat"tir. ${ }^{8}$

"Yetmiş ikisi cennette biri cehennemdedir" rivayetinin, iftirâk hadisinin daha yaygın olan varyantından daha sahih olduğunu aktaran el-Makdisî, Ahsenü't-Tekâsîm'inde söz konusu rivayeti Mürcie'nin aktardığını belirterek metni isnatsız aktarır. ${ }^{9}$ O'nun konuya ilişkin ifadelerinden; bu rivayet grubu arasında yer alıp negatif mesajı taşıyan ve "es-sevâdu'l- â'zam"1 telkin eden rivayeti bildiği de anlaşılır. ${ }^{10}$

Söz konusu rivayet grubu içerisinde pozitif mesaj taşıyan ve "Biri hariç geriye kalanın tümünün cennette" olduğu yargısına kaynaklık eden tüm rivayetler, Enes b. Mâlik'e nispet edilmiştir. Aynı kurguya sahip fakat tam zıt mesaj taşıyan "biri hariç tümü cehennemdedir" mesajı taşıan rivayet grubunun ise iki varyantı Enes b. Mâlik'e nispet edilmiştir. ${ }^{11}$ Ona nispet edilen ve farklı mesaj taşıyan bu rivayetlerden biri şöyledir:

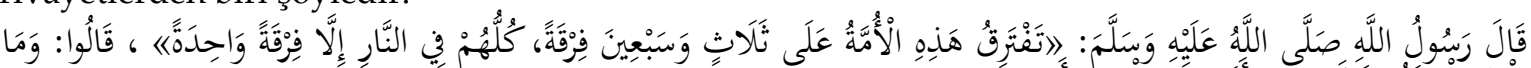

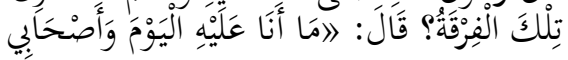

Resulullah "bu ümmet yetmiş üç firkaya ayrılacak, bunların biri hariç hepsi ateştedir" buyurdu. Denildi ki "O firka hangisidir?" Buyurdular ki "benim ve ashabımın bugün üzerinde bulunduğu şeydir."12 $\mathrm{Bu}$ rivayetin senedine iliş̧kin olarak rical uzmanları, rivayetin azîz hasen bir rivayet olduğu yargısında bulunmuşlardır. Hadisin senedindeki her râvinin de sika olduğu söylenmiştir.

Bir başka tarikten aktarılan bir rivayette ise Enes b. Malik'in kurtuluşa erecek bu fırkayı "cemâat" olarak ifade etmiş "es-sevâdu'l- â'zam" ziyadesi ile rivayeti aktarmıştır. ${ }^{13}$ Literatürde iftirâk hadisi olarak şöhret bulan ve "biri hariç tümü cehennemdedir" mesajı taşıyan rivayet, hadis edebiyatında farklı formlarda farklı lafızlar ve ziyadelerle; "biri hariç tümü cehennemdedir" ortak paydası ile aktarılmışyıtır. $\mathrm{Bu}$ rivayet grubunun sahabe tabakasından kaynakları ise oldukça kalabalıktır. Bunlar;

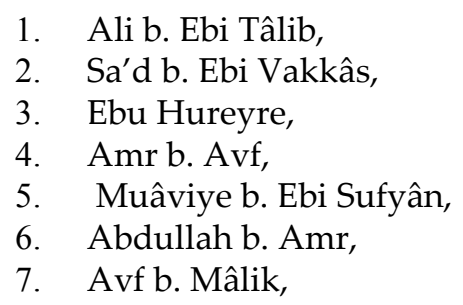

\footnotetext{
${ }^{6}$ Curkânî, el-Ebâtil ve'l-Menâkîr ve's-Sihâh ve'l-Meşâhir, 1/462, 463.

${ }^{7}$ Curkânî, el-Ebâtil ve'l-Menâkîr ve's-Sihâh ve'l-Meşâhir,1/ 464 (No. 282).

${ }^{8}$ Curkânî, el-Ebâtil ve'l-Menâkîr ve's-Sihâh ve'l-Meşâhir,1/463, 464 (No. 281).

${ }^{9}$ Muhammed b. Ahmed el-Makdisî, Ahsenü't- Tekâsîm fî Ma'rifeti'l-Ekâlîm, ed. M.J. De Goeje (Leiden: y.y., 1906), 39.

${ }^{10}$ Makdisî, Ahsenü't- Tekâsîm fì Ma'rifeti'l-Ekâlîm, 38, 39.

${ }^{11}$ Enes $b$. Malik bu rivayetin yaygın varyantını aktaran on bir sahabeden biridir.

${ }^{12}$ Curkânî, el-Ebâtil ve'l-Menâkîr ve's-Sihâh ve'l-Meşâhir, 1/465 (No. 283).

${ }^{13}$ Curkânî, el-Ebâtil ve'l-Menâkîr ve's-Sihâh ve'l-Meşâhir,1/466, 467.
} 
8. Enes b. Mâlik,

9. Ebu Umâme el-Bâhilî,

10. Vâsile b. Eska',

11. Ebu'd-Derdâ, ${ }^{1 / 4}$

İslam geleneğinde oldukça yaygın; dolayısıyla oldukça aşina olunan bu rivayet topluluğunun bir başka özelliği de ayrışmaya karşı bir tepkiyi ifade etmesidir. Söz konusu rivayetleri, birliği telkin eden metinler olarak görmek de bu yüzden olasıdır. Ayrışmaya tepki koyan, birliği teşvik eden bu rivayetler topluluğu, ayrışanların "ateşte" olduğunu ihbar eden bir mesaj taşır ve akademik çevrelerce yoğun biçimde çalışılmış ve yorumlanmıştır. ${ }^{15}$ Bu yüzden gelenekte "biri hariç tümü cehennemdedir" mesajını içeren metinlere çalışmamız çerçevesinde sadece pozitif mesaj içeren rivayetin ötekisi ve arka yüzü olmaları bağlamında yer verilecektir.

\section{Kavramsal Çerçeve}

İslam geleneği fırkalaşma ve ayrışmaya karşı "birlik" ifade eden "cemâ'at" kavramına daha yakın durmuş, ayrışma anlamı ifade eden "iftirâk"tan kaçınılmasını telkin etmiştir. ${ }^{16}$ Kur'an'da bu telkin, farklı ayet gruplarında öne çıkarılmış ${ }^{17} \mathrm{~Hz}$. Peygamber'in de söz konusu ayet grupları sebebiyle inananlarını bu konuda uyardığı literatüre yansımıştır. Söz konusu rivayetlere ihtiyatla yaklaşmak telkin edilse bile, ayetlerin tefsiri sadedinde Hz. Peygamber'in ayrışmaya karşı tavır aldığını varsaymak her hâlükârda ma'kul görünüyor. Öte yandan Müslüman bireyin şekillenmesinde yaşanmış bir dini tecrübeyi ifade eden ehl-i kitap geleneğinin, Kur'an'a konu olan anlatısı itibarıyla da Müslümanlar ayrışmaya temkinli bir duruş sergilemiş görünüyorlar. ${ }^{18} \mathrm{Bu}$ durum yalnız başına $\mathrm{Hz}$. Peygamber'in, ayrışmaya karşı arkadaşlarının dikkatini çekmesi için yeterli bir zemindir.

Ayrışma olgusuna ilişkin Kur'an metinlerinden bazıları; “...hep birlikte Allah'ın ipine simsıkı sarılın, sakın parçalanıp ayrılı̆̆a düşmeyin" 19, "Ve sakın kendilerine açık deliller geldikten sonra ayrılıklara ve anlaşmazliklara düşerek parçalanan toplumlar gibi olmayın..." 20, "Dinlerini bölüp parçalayıp sonra da grup grup olanlar var ya, senin onlarla bir işin olmaz..." 21, "Allah'a ve Resulüne itaatten ayrllmayın, aranızda çekişip birbirinize düşmeyin..." 22, "Ayrıca dinlerini paramparça eden ve çeşitli zümrelere ayrilanlardan da olmayın " 23, "...Dini dosdoğru uygulayın, onda ayrılığa düşmeyin..." 24 şeklindedir.

Söz konusu rivayetlerin her iki varyantında da dikkat çekilen ve İslam geleneğinde mezhepleşme olgusuna kaynaklık eden kavramlar, konunun anlaşılırlık kazanmasında anahtar rol oynamıştır.

A. Cemâ'at

İslam kültür geleneğinin önemli bileşenlerinden olan "cemâ'at" kavramı siyasal, kültürel ve dini referansları olan bir kavramdır. ${ }^{25}$ Ce-me-a' fiil olarak, bir araya getirmek, toplamak anlamlarına gelirken; isim olarak birliktelik, topluluk, grup, zümre anlamlarına gelir. Kavramın isim ve fiil türevlerinin tümünün, iftirâk kavramının zıddı olduğu tespit edilmiştir. ${ }^{26}$ Ebû Mutî' en-Nesefî de cemấ' $a$ kavramını iftirâk' in zittı olarak tanımlar. ${ }^{27} \mathrm{O}$, İbn Abbas'tan; "cemâ'atle birlikte hareket ederek isabet edenin amelini Allah kabul eder; şayet hata ederse Allah onu affeder. Fakat kişi iftirâk içinde ise doğruyu yapsa bile Allah onun bu amelini kabul etmez" şeklinde bir aktarım yapar. ${ }^{28}$ Bu aktarımın birey dindarlığını grup dindarlığına

\footnotetext{
${ }^{14}$ Curkânî, el-Ebâtil ve'l-Menâkîr ve's-Sihâh ve'l-Meşâhir,1/ 467.

${ }_{15}$ Muhammet Emin Eren, Hadis Tarih ve Yorum: 73 Fırka Hadisi Üzerine Bir İnceleme (İstanbul: Kuramer Yayınları, 2017); Kadir Gömbeyaz, "73 Fırka Hadisinin Mezhepler Tarihi Kaynaklarında Fırkaların Tasnifine Etkisi”, Uludağ Üniversitesi İlahiyat Fakültesi Dergisi 14/2 (2005), 147-160; Ahmet Keleş, "73 Fırka Hadisi Üzerine Bir İnceleme", Marife 5/3 (2005), 25-45; Mehmet Kubat, "73 Fırka Hadisi'ni Yeniden Düşünmek”, İnönü Üniversitesi Illahiyat Fakültesi Dergisi 3/2 (2012), 9-45.

${ }^{16}$ Bayram Çınar, “İslam Geleneğinde Mezhepleşme Algısı ve Mezhep Olgusu”, Akademik-Us 4/2 (2020), 43-70.

17 el-Bakara 2/213; Âl-i İmrân 3/105; el-En'âm 6/159; el-Enfâl 8/46; el-Rûm 30/32.

18 eş-Şûrâ 42/14; el-Beyyine 98/4.

19 Âli İmrân 3/103.

20 Âli İmrân 3/105.

${ }^{21}$ el-En âm 6/159.

22 el-Enfâl 8/46.

${ }^{23}$ er-Rûm 30/32.

${ }^{24}$ eş-Şûrâ $42 / 13$.

${ }^{25}$ Eren, Hadis Tarih ve Yorum: 73 Firka Hadisi Üzerine Bir İnceleme, 282, 283.

${ }^{26}$ Eren, Hadis Tarih ve Yorum, 281.

${ }^{27}$ Ebu Mutî' Mekhûl b. el-Fazl en-Nesefî,, Kitâbu'r-Redd 'alâ Ehli'l-Bida', nşr. Marie Bernand, Annales Islamologiques 16 (1980), 55.

${ }^{28}$ Nesefî, Kitâbu'r-Redd, 55.
} 
feda eden bir yaklaşımı telkin ettiğini, dile getirmek icap eder. Söz konusu rivayetin nerede yaptı̆̆ııızı ne yaptığınızın önüne koyması, dikkat çekicidir.

Cemâ'a kavramının belirli bir toplum tabakasına referansta bulunmayan içeriğine karşın, kavramın "bütüne" vurgu yaptığı ise açıktır. Fakat ister çoğunluk isterse azınlık olsun kavrama ilişkin gelenekte yapılan yorumlar, farklı toplum gruplarının siyasal ve ideolojik bir araç olarak cemấayı sahiplenmesine imkân vermiştir. ${ }^{29}$ Bu yüzden karşıt görüşteki sosyal gruplar, el-cemâ‘ $a$ üzerinden kendini aklayan iddialarda bulunmuştur. Bu durum siyasî veya dinî hiçbir grubu referans göstermeyen cemấat kavramının nötr oluşuyla ilgilidir.

İslam geleneğinin $e$-Cemấa kavramına ilişkin temel varsayımı Hz. Peygamber döneminde ümmetin bir bütün olduğu şeklindedir. Bu kabul mantıklı olduğu gibi realiteye uygundur. Çünkü $\mathrm{Hz}$. Peygamber, dini otoritenin kendisini temsil etmektedir ve bir alternatife imkân vermeyecek kadar onun otoritesi tartışmasızdır. İslam toplumunda varsayılan yerel otoritelerin ortaya çıkması, mezheplere imkân veren fikir hareketlerinin tarihi, bu yüzden doğal otoriteyi temsil eden $\mathrm{Hz}$. Peygamber sonrası bir döneme rastlar. Bu dönemdeki sosyal ve siyasal problem alanları, teolojik tavır farklılıklarını ortaya çıkarmış, farklı yaklaşımlar süreç içerisinde ekolleşerek dini algıyı yönetmiştir.

Tüm bunlardan sonra İslam geleneğinin mezhepleşmenin, cemâ'atı temsil eden ana gövdeden kopmalarla şekillendiği varsayılır. Söz konusu algı, kökenini, Hz. Peygamber döneminde yerel otoritelerin bulunmamasından alır. Zira Hz. Peygamber döneminde otorite tek, toplum ise birliktedir. Bu varsayıma göre Hz. Peygamber döneminde cemâ‘at, ümmet kavramının karşılığıdır ve Müslüman toplumun tümünü temsil eder. Bu dönemde toplumun çok başlılı̆̆ından ya da ayrışmasından söz etmeye de imkân yoktur. Bu yüzden Hz. Peygamber'in yaşamı ile sınırlı tutarak, cemấat kavramının içlem ve kaplamı ümmet kavramınınkiyle aynıdır. ${ }^{30}$

Uzlaşı halinde olan bu toplumun, ile'l-ebed böyle kalamayacağı varsayılarak, kargaşa ve kaos dönemlerinde toplumun mutabakatının kırılmaya uğrayacağı öngörülmüş, kırılma ve kaos dönemlerinde nasıl bir tavır takınılacağı yönetilmeye çalışılmıştır. Bu durumda da farklı çözüm önerileri gündeme gelmiş ve konuya ilişkin kavramlar zenginleşmiştir. İbn Mâce'nin cemâ'ati telkin eden söz konusu rivayete kitabu'l-fiten de yer vermesi bu yönüyle tesadüfî değildir. Öte yandan Hasan b. Ali'nin hilafet iddiasından feragat ederek, hilâfeti Muâviye b. Ebu Süfyan'a devrederek ona bey'at etmesiyle çekişmelerin sona erdiği yıla Âmu'l-Cemâ'a isminin verilmesi, kavramın yeni anlam çerçevesinin "siyasi birlik" olarak belirlendiğini gösterir. ${ }^{31}$

\section{B. Es-Sevâdu'l- Âzam}

Kavramın, 73 fırka rivayet topluluğunun bir parçası olarak ya da el-cemâ'a kavramının bir yorumu olarak literatüre girdiği düşünülür. Kalabalık- topluluk anlamı, onun el-cemâ'a yerine kullanımını güçlendirse bile, söz konusu rivayetlere yansıyan bağlamı, kavramın asıl anlam katmanını oluşturur. Mervezî, es-sevâdu'l-âzam'dan maksadın "cemâ'at" olduğunu söyler. ${ }^{32} \mathrm{Bu}$ alg1 es-sevâdu'l-âzam kavramını "cemâ'a" ile eşitleme çabası olarak görülebilir.

İslam geleneğinde cemâ'a ya da es-sevâdu'l-âzam denilince, önce Müslüman ilk kuşağa atıf yapılır, diğer tüm yapılar ise meşruiyetlerini ancak kavramın ilk anlam çerçevesinden alır. Es-Sevâdu'l-âzam kimdir (?) sorusu bu yüzden "Sahabe ve onlara tabi olanlardır" ş̧eklinde cevaplandırılmıştır. ${ }^{33} \mathrm{Bu}$ kavramın kalabalığa vurgu yapan temel anlamı, süreç içerisinde farklı bir çehre kazanarak, daha teknik bir anlama dönüştüğü de kavramın tarihi içerisinde görülür.

Es-Sevâdu'l-âzam'ın tam olarak neyi ifade ettiği konusunda farklı görüşler dile getirilmiştir. Ulemadan bazıları niteliklerinden bağımsız olarak kalabalığı teşkil eden insanlar topluluğu olduğunu dile getirmiş, bazıları bunun hakkı temsil eden insanlar topluluğu olduğunu söylemiştir. Diğer bazıları ise daha elitçi bir anlayış ile bunun ictihad yapma salahiyetinde olan âlimler olduğunu söylemişlerdir. ${ }^{34}$ Başka bir grup âlim ise bunun ille de bir grup olması gerekmediği, tek kişi olsa bile hakkı temsil ediyor ise bu

\footnotetext{
${ }^{29}$ Ebu'l-Hasen b. Ahmed el-Hemedanî, Kâdî Abdulcebbâr, “Kitab Fadlu'l-İtizal ve Tabakâtu'l-Mu'tezile ve Mubayenetihim liSaîri'l- Muhalifin", Ebu'l-Kasım Belhî, ,Kâdî Abdülcebbar, Hâkim el-Cüşemî, Kitab Fadlu'l-İtizal ve Tabakâtu'l-Mu'tezile thk. Fuâd Seyyid (Beyrut: Dâru'l- Fârâbî, 2017), 148, 149.

${ }^{30}$ Abdülkahir el-Bağdadî, el-Fark Beyne'l-Fırak thk. Osman el-Huşî (Beyrut: Dâru'l-âfâk el-Cedide, 1977), 32.

31 Şihâbuddin Ahmed b. Muhammed el-Endulûsî İbn Abdirabbih, el-ìkdu'l-Ferîd (Beyrut: Dâru'l-Kutubi'l-İlmiyye, 1404), 4/170.

${ }^{32}$ Nasr b. Haccac el- Mervezî, es-Sunne thk. Sâlim Ahmed es-Selefî (Beyrut: Muessestu'l-Kutubu's-Sekafiye, 1408), 22 (No. 56).

${ }^{33}$ Ebu İshâk Şâtibî, el-'ं'tisâm thk. Selim b. 'İyd el-Hilalî (Sudi Arabistan: Dâr ibn Affân, 1992), 777.

${ }^{34}$ Muhammed Ebu Kerim, Vasıtıyyetu ehle's-Sunne beyne'l- Firak (b.y: Dâru'r-Râye, 1994), 95.
} 
nispetin kendisine yapılabileceği şeklinde olmuştur. ${ }^{35}$ Bu bağlamda İbnü'l-Kayyım'ın "bir çağda sünneti bilen tek kişi olsa icmâ odur. Es-Sevâdu'l-âzam'ı o temsil eder. Bu durumda ona uyulması icap eder" dediği kaydedilmiştir. ${ }^{36}$ Şâtıbî ise; es-sevâdu'l-âzam'ın müçtehitlerden olması gerektiği, mukallitlerden olamayacağını ifade ederek, kavramın "niteliksiz kalabalık" anlamının dışında, elitçi bir yorumunu yapar. $^{37}$

\section{Firka}

Kavram olarak grup, topluluk anlamı veren fırka, İslam kültür geleneğinde mezhep kavramına karşılık kullanılmıştır. İslam geleneğinde itikadi, siyasi ve fikhi bütün birliktelikler firka kavramı dağarcığı ile karşılanmıştır. İftirâk hadisinin sağladığı algı ile "el-firaku'd-dâlle" ve "el-firkatu'n-nâciye" şeklinde bir ayrım ise kavramın hak-batıl düzlemindeki bir yorumudur. Gelenekte kullanılan hali ile bu iki kavram, bir paranın iki yüzü gibidir, bu yüzden "el-firaku'd-dâlle"ye ilişkin konuşmak, "elfirkatu'n- nâciye"nin anlam çerçevesini de belirler.

“İsrailoğulları yetmiş bir firkaya ayrıldı. Benim ümmetim ise yetmiş üç fırkaya ayrılacaktır. Es-Sevâdu'lâzam hariç; diğerlerinin tümü ateştedir" ${ }^{38}$ şeklindeki rivayette, es-sevâdu'l-âzam metninin bir parçasıdır. Taberânî ve Acurrî, bu rivayeti "kulluha ale'd-dalâleti illâ es-sevâdu'l-âzam" ziyadesi ile kaydetmiştir. ${ }^{39}$ Böylece el-firaku'd-dâlle, el-firkatu'n-nâciye'yi temsil eden es-Sevâdu'l-âzam kavramının ötekisi konumuna gelmiş ve gelenekte böyle anlaşılmıştır.

Cemâ'at olan "ümmet”ten ayrılanların, kendi alternatif cemấatlerini oluşturdukları firak geleneğinin temel kabullerinden biridir. Ayrışmaların yetmiş üç fırkaya ulaşacağı ve bunlardan sadece birinin kurtulacağı, gerisinin ise dalâlette oldukları da söz konusu kabulün bir parçasıdır. Teoriye göre cemâ'atin bakiyesi olan ve ashabın baştan beri takipçileri konumunda olanlar ise sahabenin dolayısıyla doğru İslam'ın temsilcisidirler. Sünnetin takipçileri oldukları varsayılan bu kitlenin, sahabenin mirasını tevarüs eden Ashâbu'l-hadis oldukları da bu yüzden varsayılır. Onların literal anlamı ile "ashabın yolunun takipçileri" oldukları, rivayetle iştigal etmeleri sebebiyle ma'kuldür. Dolayısıyla bu ekolün, bölünmekten kaçınan ve geçmişin izinin takipçileri olarak, kurtulacak olan "elfirkatu'n-nâciye" oldukları da bu kabullerin bir sonucu olarak, genel bir temayül olarak onaylanmıştır. Onlara ilişkin ehlu's-sunne, ehlu'l-hak şekliyle yapılan nispetler, geçmişin mirasçıları; Hz. Peygamber ve onun ashabının yürüdüğü yolun temsilcileri oldukları varsayımına dayanır. ${ }^{40}$ Buna göre; ana gövdeden ayrılan bütün kitleler ise söz konusu rivayetlerin sağladığı imkânlar ile dalâlette olan fırkalar olarak görülmüş̧ür. İbn Hacer, Ehl-i sünnetin es-sevâdü'l-âzam olduğunu, Allah'ın, sahabeden sonra, onları dinde hüccet kıldığını kaydeder. ${ }^{41} \mathrm{Bu}$ anlayışa paralel bir biçimde Bağdadî, yetmiş üç fırka hadisinin bir parçası olarak değerlendirdiği es-sevâdu'l-âzam'ı, "cemấat" kavramı gibi çatı bir kavram olarak ele alır. El-Fırkatu'n-nâciye'nin, es-sevâdu'l-ấzam olduğunu söyler ve onların dini inançlarını özetler. ${ }^{42}$ Bu yorumlarda Ashâbu'l-hadis merkezi bir konumdadır.

İslam kültür geleneğinde gerek es-sevâdu'l-âzam gerekse "cemâ'at" kavramı firka ve firak kavramının ötekisi olarak birliği temsil eden kavram çiftidir. Fırakı temsil eden ayrılıkçı yapılar ise küfür ile olmasa bile dalâlet ve sapkınlık ile etiketlenmiş ve teolojik olarak heretik ilan edilmişlerdir. Zira rivayetin meşhur olan varyantlarında "kulluha fi'n-nâr" denildiği bu bağlamda unutulmamalıdır. ${ }^{43}$

\section{Rivayetler Topluluğuna İlişkin Değerlendirme}

Sözü edilen rivayetler topluluğunun iki farklı varyantı iki temel yargıdan oluşur. Bu yargıdan ilki; "Ümmetim........ firkaya ayrllacaktır"

\footnotetext{
${ }^{35}$ Galib b. Ali 'İvecî, Fıraku Muassira tentesib ile'l- İslam ve beyanu mefkifu'l- İslam minha (Cidde: Mektebetu'l-Asriyye ez-Zehebiye, 2001),1/100, 101.

${ }^{36}$ Ebu Kerim, Vasitıyyetu ehle's-Sunne beyne'l- Firak, 96.

${ }^{37}$ Ebu İshâk Şâtibî, el-Muvâfakât thk. Ebu Ubeyde Meşhur (Sudi Arabistan: Dâr ibn Affân, 1997), 5/140.

${ }^{38}$ Ebu Bekr Muhammed b. el-Huseyn el- Âcurrî, Kitâbu'ş-Şerî‘ a, thk. Abdullah b. Ömer ed-Dumeycî (Riyad: Dâru'l-Vatan, 1997), 1/ 312, 313 (No. 27) ; Abdullah b. Muhammed b. Ali el- Herevî, Zemmu'l-Kelam ve Ehlihi, (Medine: Mektebetu'l-Ğurebâi'lEseriyyye, 1998), 1/65 (No. 53).

39 Âcurrî, Kitâbu'ş-Şerî‘a, 1/432,433 (No. 111) ; Ebu'l-Kâsım Suleyman b. Ahmed b. Eyyûb et-Taberânî, el-Mu'cemu'l-Kebîr, thk. Hamdi b. Abdulmecîd es-Selefî (Kahire: Mektebetu İbn Teymîyye, 1994), 8/ 152 (No. 7659).

${ }^{40}$ Abdülkahir el-Bağdadî, el-Fark Beyne'l-Fırak, 21.

${ }^{41}$ Askâlanî İbn Hacer, Fethu'l- Bârî, thk. Abdu'l- Aziz b. Abdullah b. Bâz (Beyrut: Dâru'l-Mârife, 1379), 13/37.

42 Abdülkahir el-Bağdadî, el-Fark Beyne'l-Fırak, 272-317.

${ }^{43}$ Ebu Bekr İbn Ebî Asım, es-Sünne thk. Nâsruddin el- Albanî (Beyrut: el-Mektebetu’l- İslamiye, 1400), 1/34 (No. 69).
} 
$\mathrm{Bu}$ temel yapıya eklemlenen ifadeler ile metin daha zengin bir görünüme kavuşsa bile rivayetler topluluğunun iskeletini, ümmetin kaç gruba ayrılacağı yargısından oluşur. Metni zenginleştiren söz konusu ifadeler, çoğu zaman rivayetler arasındaki lafız farklılıkları sebebiyle mümkün olabilmiştir. ${ }^{44}$ Rivayetlerde yer alan zenginleştirici bu lafız farklılıklarının bazıları "Yahudiler yetmiş bir ya da yetmiş iki firkaya ayrıldılar. Hiristiyanlar da yetmiş bir ya da yetmiş iki firkaya ayrıldılar" 45 gibi kıyaslamalar barındırır. Sayılara ilişkin bu tereddüt, rivayetin kalan bölümüne de sirayet etmiş ve bazı rivayetlerde "yetmiş üç"46 ifadesi kullanılırken diğer bazılarında ise "yetmiş küsur"47 şeklinde olmuştur. Öte yandan bu rivayetlerin bazılarında yalnızca benu İsrâil zikredilmişken bazılarında ise Hristiyanlara hatta Mecusilere yer verilmiştir. ${ }^{48}$ Şehristânî, Mecusilere de atıf yapan böyle bir rivayeti kendi kurgusuna temel alır. ${ }^{9}$

Rivayetlerin taşıdığı ikinci yarg1 ise

"Bunlardın biri hariç, geriye kalan firkalar......dir"

Metnin ikinci yargısı da metinler arası lafız farklılıklar ve ziyadeler sebebiyle zengin bir anlam dağarcığını barındırır. Bu rivayetlerin bazılarında metnin ana gövdesinin de değiştiği görülür. Bunlarda fırka yerine "mille" ifadesinin kullanıldığı da görülür. ${ }^{50}$ Öte yandan bazı rivayetlerde sadece cemâ'a lafzı kullanılırken ${ }^{51}$ bazı rivayetlerde ise cemâ'at, es-sevâdu'l-âzam ile tefsir edilmiştir. ${ }^{52}$ Diğer bazıları ise "bizim; (benim ve ashabımın), bugün üzerinde olduğu şey"53 "benim ve ashabımın üzerinde olduğu şey" 54 şeklindeki ziyadelerle aktarılmıştır.

Söz konusu ziyadeler ve lafız farklılıkları göz ardı edilse bile, söz konusu rivayet topluluğunun taşıdığı mesaj da iki rivayet varyantı açısında farklılık gösterir. Zira rivayetlerden biri; biri hariç ötekilerin tümü cehennemdedir mesajı taşıyorken, diğer varyantında biri hariç diğerleri cennettedir mesajı taşır. Bu fark, iki rivayeti çelişik hale getirir ki bu durumda; yargılardan biri doğru ise diğerinin doğru olma ihtimali yoktur.

İslam ulemasından bazıları söz konusu fırkaların kıyamete kadar tamamlanamayacağı kanaatinde olduğu, diğer bazılarının ise tarihe tabi olarak, bölünmenin tamamlandığı değerlendirmesi ile hareket etmiş görünür. ${ }^{55}$ Kendilerine kadar oluşan süreçte yetmiş üç fırkayı arama gayretleri, bu algının bir tezahürüdür.

\section{Rivayetler Topluluğunun Yorumu}

"Hepsi Cennettedir, biri müstesna" rivayet grubu, farklı varyantlarına karşın, bir bütün olarak Enes b. Malik'ten aktarılmıştır. Söz konusu rivayetlerin bütünü hadis uzmanları tarafından farklı gerekçelerle illetlendirilmiş ve rivayetin mevzu olduğuna, hükmedilmiştir. Rivayetin sıhhatine ilişkin bu sorun, pozitif çağrışımları ve daha kucaklayıcı görünmesine karşın, rivayetin alanda şöhret bulmasını engellemiştir. Makdisî'nin, daha sahih olduğunu düşündüğü bu varyantın, doğru kabul edilmesi

\footnotetext{
${ }^{44}$ Muhammet Emin Eren, “İftirak Hadisinin Anlaşılma Biçimleri Üzerine”, Ankara Ünivesitesi İlahiyat Fakültesi Dergisi 55/2 (2014), 59-97.

${ }^{45}$ Süleyman b. Eş'âs b. İshak es-Sicistânî Ebu Dâvûd, es-Sunen, thk. Muhyiddin Abdulhamid (Beyrut: Mektebetu'l-'Asriye, ts.), "Kitabu's- Sunne", 4596) ; Ebu Bekr Ahmed b. el-Huseyn b. Ali el-Beyhakî, es-Sunenu'l-Kubrâ, thk. M. Abdulkâdir Atâ (Beyrut: Dâru'l-Kutubi'l- İlmiyye, 2003) (No. 20901); İbn Hibbân, Sahîhu İbn Hibbân thk. Şuayb el-Arnavûd (Beyrut: Müessesetü'r-Risâle, 1993), 14/140, "Kitabu't-tarih", 6247.

${ }^{46}$ Ebû Abdullah Ahmed b. Muhammed eş-Şeybani Ahmed b. Hanbel, el-Müsned, thk. Ahmed Muhammed Şâkir (Kahire: Dâru'lHadis, 1995), 8/301 (No. 8377).

${ }^{47}$ İbn Batta, el-İbâne el-Kubrâ, 1/368 (No. 263).

${ }^{48}$ Eren, Hadis Tarih ve Yorum: 73 Firka Hadisi Üzerine Bir İnceleme, 123.

${ }^{4}$ Ebu'l-Feth Muhammed b. Abdulkerim eş-Şehristânî, el-Milel ve'n-Nihal, thk. Ahmed Fehmi Muhammed (Beyrut: Dâru'l Kutubu'l-ïlmiyye, 1992), 1/4.

${ }^{50}$ Hibetullah b. Hasan b. Mansur el-Lâlekâî, Şerh Usuli I'tikad Ehli's-Sünne ve'l-Cemâ'a, thk. Sa'd el Gâmidî (Suudi Arabistan: Dâru Taybe, 2003), 1/112,113 (No. 147, 150); Ebu Abdillâh el-Hâkim en-Nîsâbûrî, el-Mustedrek ale's-Sahihayn thk. Mustafa Abdulkadir Atâ (Beyrut: Dâru'1 Kutubu'l-İlmiye, 1990), 1/218 (No. 444); Ebu Dâvûd, es-Sunen, "Kitabu's- Sunne", 4597.

51 İbn Batta, el-íbâne el-Kubrâ,1/367, 368 (No. 263).

52 Mervezî, es-Sunne, $1 / 22$ (No. 56).

53 İbn Batta, el-íbâne el-Kubrâ, 1/167.

${ }^{54}$ Muhammed b. İsa et-Tirmizî, el-Câmi'u'l-Kebîr (Sunenu't-Tirmizî), thk. Beşşâr Avvâd Mahfûz (Beyrut: Dâru'l- Garb el- İslamî, 1998), “Ebvabu'l-İmân", 2641.

${ }^{55}$ Ebu'l-Muzaffer İsferâyînî, et-Tabsir fi'd-Din ve't- temyizu'l-Fırkate'n-Nâciye ani'l-Fıraki'l-Hâlikin thk. Kemal Yusuf el-Hut (Beyrut: Alemu'l Kutub, 1983), 16.
} 
durumunda, İslam ümmetinin sadece bir fırkası dalâlet üzeredir ve sadece biri helak olacaktır, geriye kalanlar hak üzeredir dolayısıyla cennettedir. Ona göre helak olacak bu fırka Bâtınîler'dir. ${ }^{56}$ Onun bu yargısının izdüşümünü sürdürdüğümüz takdirde, Bâtınîler dışındaki mezhep ve ekoller birbirilerini, dalâlette olmak, bid'atçi olmak ve kâfir olmakla itham etmeyecektir. Zira arta kalan ekollerden her biri, kendilerini hakikatin bir parçası olarak algılayacaktır. Bu durumda; "sadece ben doğruyu temsil ediyorum geriye kalan herkes yanlış üzeredir" yargısının oluşmasına ihtiyaç da imkân da kalmayacaktır. Fakat bu söyleme mesnet teşkil eden rivayetin sıhhatten yoksun olduğu varsayıldığında- ki hadis otoritelerinin kanaati bu yöndedir- bu metnin sağlayacağı sosyal ve kültürel imkânlar da anlam kaybına uğrar.

Makdisî, pozitif vaadlerde bulunan ve "bana göre daha güvenilir" diyerek isnatsız olarak aktardığ1 bu rivayetin isnadını, sahip olduğu illet sebebiyle eserine kaydetmemiş görünüyor. Zira illetli olan isnadını eserine almış olsa; konuya ilişkin polemik yapmasına imkan kalmayacağı gibi, bu rivayetin daha güvenilir olduğunu söylemeye de olanak bulamayacaktır. $\mathrm{O}$, böyle bir polemik yapabilmek imkanını elde etmek amacıyla muhtemelen, isnadı kaydetmemeyi tercih etmiştir. Bu durumda "bana daha güvenilir görünüyor" ifadesi rivayetin aktarım kanalının güvenilirliğini değil, muhtemelen rivayetin uyandırdığı pozitif mesajın daha kucaklayıcı olması sebebiyle Makdisî tarafından İslam'ın ruhuna daha uygun bulunduğu anlamına gelir.

Bir coğrafyacı ve seyyah olarak Makdisî, farklı fırka mensuplarının dindarlık algılarını ve yaşamlarını yakından görme fırsatı bulmuş ve söz konusu rivayetin meşhur varyantında "biri hariç diğerleri cehennemdedir" mesajı ile karşılaştı̆̆ realiteyi örtüştürmekte İslam dindarlığ zorluklar yaşamış, rivayetin daha az bilinen versiyonu ile karşılaşınca da bunu yaşadığı realiteye daha yakın bularak, onaylama eğiliminde olmuştur denilebilir. Zira farklı ekol dindarlıkları arasındaki yaşam ve anlayış farklarının hak-batıl çizgisinde değil, hakikatin alt kümeleri olarak görülmesi, onun yaşadığı kültürel koşullara daha uygun bir yorumdur. Anlayışları ve inançları arasında uçurum olmayan bu yapıları heretik ilan etmek, muhtemelen onun anlamakta zorlandığı bir yorumdu. $\mathrm{Bu}$ yüzden iftirâk hadisinin daha pozitif bir mesaj veren versiyonunu vakıaya daha uygun bulmuştur.

Makdisî, negatif mesajı olan ve alandaki meşhur varyantın kabul edilmesi durumunda oluşacak denklemi de ortaya koyar. Buna göre kurtulacak (nâciye) olan; kalabalık topluluktur (es-sevâdu'l-âzam) diyerek; bunların İslam coğrafyasının farklı bölgelerinde farklı mezhepler olabileceğini varsayar. EsSevâdu'l-ấ'zam'ın; Hanefiler, Malikiler, Şafiîler ve Ashâbu'l-hadis olacağını söyler. Onun söz konusu rivayete ilişkin bu yorumunun ilginç üç yönü var. Bunlardan ilki, sayılan ekoller akâid ekolleri değil fıkıh ekolleridir. İkincisi, onun kurtuluş teorisinde kurtulacak ekol bir değil birden fazladır. Üçüncüsü ve daha ilginç olanı ise o, "es-sevâdu'l-âzam" kavramını literal anlamıla ele alarak, İslam coğrafyasında hangi ekol nerede ekser yoğunluğu temsil ediyor ise orada "nâciyedir" gibi bir yorumda bulunmuştur. Buna göre Hanefiler yoğun oldukları doğu bölgesinde es-sevâdu'l-âa'zam'ı temsil eder ve ancak burada kurtulmuş olmakla müjdelenmiştir. Malik'in ekolü ise Mağripte kurtuluşa erecek fırkadır... Onun bu yorumuna göre; ekollerin öğretilerinden kaynaklanan bir sebeple mutlak bir kurtuluşundan söz edilemez. Zira onun bu yorumu, ekolün öğretisinin sıhhatine değil kalabalık olduğu bölgeye odaklanır. Bu durumda, sıhhatin kaynağı, ekolün öğretisinden değil, kalabalık oluşundan kaynaklanmış, meşruiyet; öğretinin sıhhatinde değil kalabalıkta aranmıştır. Peki, ama Şam'da olan Hanefi, Şâfiî ve Malikîlerin durumu ne olacaktır? Zira Makdisî̀ye göre Şam'da essevâdu'l-ấ'zam'ı Ashâbu'l-hadis temsil eder. Peki diğer mezheplerin yoğun olduğu bölgelerde Ashâbu'lhadis'in durumu ne olacaktır? Makdisî'nin kurgusunda bunun cevabı verilmemiştir. ${ }^{57}$

"Hepsi Cehennemdedir biri müstesna" rivayeti, farklı varyant, lafız ve ziyadeler ile aktarılmış olmasına karşın, bu rivayet topluluğu hakkında hadis otoriteleri tarafından daha olumlu bir yargıya ulaşılmış, bunun bir sonucu olarak rivayet, gelenekte şöhret bulmuş, söylem-etki gücü artmış ve metin mezhepleşme geleneğinde şekillendirici bir nitelik kazanmıştır. Bu rivayetin yorumundan kaynaklanan sebeplerle, İslam kültür geleneğinde bir ötekileştirmenin yapıldığı, bu rivayetin "tekfirci" anlayışları beslediği bu yüzden varsayılabilir. Fakat bu rivayet grubunun bir varyantında ötekileştirmeye karşı mesafeli metinlere de yer verilmiştir. Bu rivayete göre;

“Bir gün dinle ilgili bir meselede tartıştı̆ııız sırada Resulullah yanımıza geldi. Bu duruma çok öfkelendi. Daha önce böylesine öfkelenmemişti. (...) Tartışmaktan vazgeçin; Zira İsrâiloğulları yetmiş bir fırkaya ayrıldı. Hıristiyanlar da yetmiş iki fırkaya ayrıldı. Bunların tümü dalâlet üzeredir. Sadece es-sevâdu'l-âzam bunun

\footnotetext{
${ }^{56}$ Makdisî, Ahsenü't-Tekâsîm fî Ma'rifeti'l-Ekâlîm, 39; Betül Yurtalan, “Bir Coğrafyacının Gözünden Mezhepler: el-Maḳdisī'nin Aḥsenu't-Tekāsīm'inde Mezhepler Bahsinin Tahlili”, Ankara Üniversitesi Ilahiyat Fakültesi Dergisi 62/ (2021), 135-168.

${ }^{57}$ Makdisî, Ahsenü't-Tekâsîm fî̀ Ma'rifeti'l-Ekâlîm, 40, 41.
} 
dışındadır buyurdu. Orada bulunanlar “Ey Allah'ın Resulü es-sevâdu'l-âzam kimdir?” diye sordular. "Benim ve ashâbımın yolu üzere olanlar, Allah'ın dini üzerinde tartışmaya girmeyenler ve tevhid ehlinden hiç kimseyi affedildiği bir günahı sebebiyle tekfir etmeyenlerdir" buyurdu. Devamla Hz. Peygamber şöyle buyurdu: "İslam garip başladı, garip kalacaktır". Denildi ki: “Ey Allah'ın Resulü, garipler kimlerdir?” “İnsanları 1slah edenler, Allah'ın dini konusunda tartışmaya girmeyenler ve bir günahtan dolayı tevhid ehlinden birini tekfir etmeyenlerdir." 58

Ebu Umâme tariki ile aktarılan bu metne göre; ashâb dini bir konu üzerine ateşli bir biçimde tartışmaktadır. Resulullah ise bu duruma çok sinirlenerek onlara nasihatte bulunur ve onları yatıştırma sürecinin bir parçası olarak, hadis edebiyatında iftirâk hadisi olarak bilinen metnin bir varyantını dile getirdiği anlaşılıyor. Bu rivayetin ilginç yönü es-sevâdu'l-ấzam vurgusu ile benim ve ashabımın üzerinde olduğu yol vurgusuna birlikte yer verilmiş olmasına ek olarak etimolojik çağrışımları güçlü ve kalabalığı ifade eden es-sevâdu'l-âzam'ın zayıf ve örselenmiş "garîb" kavramı ile tefsir edilmesidir. Söz konusu metinde vurgu yapılan bir diğer nokta da metnin bağlamı ile ilişkili olarak; tartışmadan uzak durmak ve insanları günahları sebebiyle tekfir etmemek mesajının muhataplarına telkin edilmiş olmasıdır. Buradan hareketle, günahları sebebiyle tartışmanın taraflarının birbirlerini tekfir ettikleri ve bu durumun da Hz. Peygamber'i oldukça rahatsız etmiş olduğu söylenebilir.

Farklı varyantları ile hadis edebiyatında mezhepleşmeye kaynaklık eden ve kurtuluş teorisine mesnet olan iftirâk rivayetleri, öte yandan İslam ümmeti içerisinde heretik/sapkın iddiasına da zemin olmuş metinlerdir. Söylem gücü itibarıla mezhep tarihçilerinin alan değerlendirmelerinde belirleyici olan bu ahâd haber, bir rivayet olarak sahip olduğu sihhat gücünden çok daha fazla bir etki gücüne sahip olmuştur. Bu denli geniş varyanta sahip olan ve sahabe neslinden bu denli kalabalık aktarım popülasyonu olan bir habere ilişkin yapılabilecek en kolay şey, görmezden gelmek ve metnin sıhhatine ilişkin konuşmaktır..$^{59}$

Resulullah bu sözü söyledi mi şeklinde bir değerlendirmeyi yapabilecek durumda değiliz. Fakat rivayetin hangi zaman diliminde yaygınlık kazandığını tespit etme imkânımız olduğu gibi, metnin çeşitli formülasyonlarını bugünden görebilme imkânına sahibiz. Farklı metinlerin mukayesesi bize bu imkânı verir görünüyor. Diğer yandan senet(ler)deki rical tahkikleri ve metni aktaran hadis ricalinin cerh ve tadil değerlendirmelerine de bugün sahibiz. Metnin verdiği mesajların İslam dindarlı̆̆ının zihin inşasında nasıl bir etki yaptığı da rivayetler topluluğuna ilişkin elimizdeki veriler arasındadır. ${ }^{60}$ Öte yandan bu rivayetin de her rivayet gibi bir bağlamı vardır ve bu bağlamdan koparıldığı takdirde metnin yorum kaldırır bir tarafı vardır. Metnin varsayılan söylem gücü de zaten onun yoruma açık metninden kaynaklanmaktadır. Bu yüzden, bütün metinleri birlikte ele alarak bir karar vermek durumundayız. Tüm farklılıklarına karşın bu rivayetler topluluğu aynı bağlama ait bir tek rivayetin farklı aktarımları mıdır? Yoksa söze konu bu farklı varyantların, her birinin ayrı bağlam ve yerlerde söylendiği mi kabul edilecektir? Yani bağlamları ve metinleri birbirine yakın olsa ve aynımış imajı uyandırsa bile bunlar ayrı rivayetler midir? Resulullah farklı zaman dilimlerinde bu rivayetlere yansımış metinleri dile getirmiş olabilir mi? Bu durumu bir olasılık olarak görmemize imkân veren şey, rivayetin bazı varyantlarında salt mesaja ek olarak bağlamın da aktarılmasıdır. Öte yandan tüm bu rivayet kümesini bir tek bağlama indirgeyerek ele almaya da imkân var. Bu durum, söz konusu rivayetin doğasından kaynaklanan bir husustur ve bu durum rivayetlere ilişkin yorumda ayrı bir zorluk alanı oluşturur.

Hadis külliyatına yansıdığı şekliyle bu rivayet kümesinin bazı eserlerde bağlamından soyutlanarak, sadece mesajı aktarılmışken, diğer bazıları bağlamı da metne dâhil etmişlerdir. Bağlamları aktarılmamış olsa bile Resulullah'ın bir bağlam içinde ve bir kompozisyonun parçası olarak söz konusu uyarıyı yaptığı muhakkaktır. Fakat bu bağlam sadece aktarıldığı biçimi ile Müslümanların hararetli tartışmalarının neticesi olarak onlara yaptığ ihtimali, bu rivayet topluluğunu bütünüyle izah etmekte yetersiz kalacaktır. Zira diğer bazı varyantlara yansıdığı şekliyle, Resulullah bir Yahudi mühtedisi olan Abdullah b. Selâm'a dönerek Yahudilerin kaç gruba ayrıldığını sorduğu da aktarılmıştır. ${ }^{61} \mathrm{Bu}$ tablo "daha önce bu kadar sinirlendiği görülmemiş" olan Resulullah'ın başvurabileceği bir davranış kalıbı olamaz. Zira psikolojik ortam, bu iki bağlamı birleştirmeye imkân vermez. Bu durumda en az iki farklı bağlamdan söz etmek icap eder.

\footnotetext{
${ }^{58}$ Taberânî, el-Mu'cemu'l-Kebîr, 8/152 (No. 7659).

59 Özden Kanter, “Kurtuluşa Eren Fırka/el-Fırkatu'n-Nâciyye İnanc1”, Hitit Üniversitesi İlahiyat Fakültesi Dergisi 16/31 (2017), 2946.

${ }^{60}$ Osman Oral, “73 Fırka Hadisinin Kelâm İlmi Açısından Değerlendirilmesi”, Kelam Araştırmaları Dergisi 12/2 (2014), 295-313.

61 Abdurrazzâk, el-Musannef,10/156, "Kitabu'1- Lukata", 18675.
} 
Bu bağlamlardan ilki Resulullah'ın sinirlendiği tartışma ortamına ilişkin bağlamdır. Diğeri de daha sakin olduğu ve Yahudi kökenli Müslümana; Yahudilerin kaç gruba ayrıldığını sorduğu bağlamdır. Zira Kâtade'nin aktardığına göre "Resulullah, Abdullah b. Selâm'dan İsrail oğullarının kaç gruba ayrıldıklarımı sordu, o da yetmiş bir ya da yetmiş iki dedi", bunun üzerine Resulullah da "benim ümmetim de onlar kadar ya da onlardan bir fazla gruba ayrllacaktır. Biri hariç hepsi cehennemdedir" 62 buyurmuştur. Bu iki bağlamdan daha geç olanın ise sinirlendiği olay olduğu varsayılabilir. Çünkü ilk bağlamda bilmediği bir şeyi, ehline sorarak öğrenmiş ve sorduğu kişinin bilgisine dayalı olarak daha önce öğrendiği bu bilgiyi ikinci bağlamda kullanmıştır. Allah'tan vahiy alması hasebiyle Hz. Peygamber' in, birilerinden bir konuda soru sorarak öğrenme olasılığını bazı çevreler, kabullenmez. Zira zihinlerdeki "ona bilmek istediğini Allah bildirir" algısı, birilerinden öğrenmesi imkanını ona bahşetmesini içermez, bu anlayışa göre; Resulullah'ın bunu kimseden öğrenmesine gerek olmadığı, ihtiyacı halinde rabbi ona vasıtasız olarak vahiyle bildirir şeklindedir. Fakat her halükarda bu rivayet topluluğunun en az bir varyantında $\mathrm{Hz}$. Peygamber'in, bunu Yahudi kökenli bir Müslümandan sorarak öğrendiği metinlere yansımıştır. Rivayetlerin birçoğunda Hristiyanlara ilişkin değerlendirmelerin olmaması, bununla izah edilebilir görünüyor.

Bu rivayet topluluğunu fiten bağlamında ele alan, metinlere de hadis edebiyatı içerisinde rastlanır. Buna göre; mademki Hz. Peygamber böyle bir şey söyledi, söylediğgi şey söylediği biçimde mutlaka olacaktır, şeklindedir. Ali b. Ebi Talib'den aktarılan bu yöndeki bir rivayette, muhtemelen dönemindeki siyasal hareketliliği yorumlamak için bu argüman gündeme gelmiştir. Bu rivayette, kurtuluşa erecek olan tek fırkadan (nâciye) söz edilmiş olsa da bunların kim olduğuna ilişkin bir ifade metne yansımamıştır. Metinde, yetmiş üç değil, yetmiş küsur (bid've seb'in), fırka yerine (mille), cehennem yerine haviye ifadesi kullanılmış olsa da hadis literatüründe mana ile aktarımın cevazına ek olarak, metnin doğrudan Resulullah'tan değil, Ali b. Ebi Talib'in, Hz. Peygamber'in değerlendirmesinden yaptığ çıkarım olması sebebiyledir denilebilir.

Bu rivayette kullanılan bid' ve seb'in ifadesi ki başka rivayetlerde de bu ifadeye yer verilmiştir. İsrail oğullarının sayısına dayandırılan ve "onun kadar ya da ondan bir fazla" olacağı söylendiği ve İsrail oğullarının yetmiş bir ya da yetmiş iki gruba ayrıldığı, bilirkişi tarafından ifade edildiği için, daha güvenilir konumda olan, yetmiş küsür tercih edilerek, yaklaşık değer ifadesi metinlere de yansımış olabilir. Öte yandan Zâzân, Ali b. Ebi Talib'in “ Bu ümmet yetmiş küsur grup/firka/millete ayrılmadıkça kıyamet kopmaz. Bunların biri hariç tümü cehennemdedir" dediğini aktarır. ${ }^{63}$

Metinde - ister Hristiyanlara vurgu yapılmış hali ile olsun; ister ehl-i kitap şekliye dile getirilmiş olsun, isterse de sadece " benî İsrail" vurgulanmış olsun - İslam ümmeti kendi benzerlerine yaslanarak bir değerlendirmeye tabi tutulmuştur. Benzer yapıların benzer özellikler taşıdıkları, dolayısıyla benzer kırılmaları göstereceklerine de bu rivayette vurgu yapılmıştır. Özellikle kendi tasniflerinde bu rivayete merkezi bir değer atfetmiş mezhep tarihçilerinin metnin bir yarısını oluşturan; "bu ümmetin yetmiş üçe bölüneceği" varsayımıyla tasniflerini şekillendirmişlerdir. Fakat metnin diğer yarısını oluşturan ehl-i kitabın kaç gruba ayrıldığı ile ilgilenmemiş görünüyorlar. Oysa bu bölüm, metnin sıhhatini test etmede diğer bölüme kaynaklı̆̆ 1 açısından daha önemlidir. Zira metnin sıhhatini buradan test etmek mümkün görünüyor. Çünkü metnin ehl-i kitap ile ilgili boyutu, tamamlanmış bir olgu olarak sunulmuştur. Oysa Müslüman ümmetine ilişkin yönü gelecekte tamamlanacaktır. Bu yüzden metin tenkitçilerinin, fütürolojinin konusu olan bölümüne yorum yapmak yerine, metnin olgusal olan ilk yarısı üzerinde yoğunlaşmaları beklenirdi. Çünkü bilinenden-bilinmeyene çözüm yönteminde, eldeki verilerin kullanılmasıyla ancak bilinmeyene ulaşılabilir. Bu örnekte bilinen, İsrail oğullarına ilişkin metne yansıyan söylemdir. Burada Yahudiler ".... fırkaya ayrılmışlardır" denilmektedir. Rivayetin sıhhati tartışması yerine Yahudilerdeki durumun gerçekte ne olduğunun tespit edilmesi beklenirdi. Metnin bu bölümü ile ilgili söylenenler test edilerek rivayetin $\mathrm{Hz}$. Peygamber'e aidiyetine ilişkin olgusal bir kanaate varılabilirdi. Rivayetin Müslümanlara dair olan boyutu geleceğe ilişkindir ve bunun ne zaman gerçekleşeceğine matuf bir öngörü de sunmaz. Bu durumda "bu ümmet yetmiş küsur firkaya ayrılmadıkça kıyamet kopmaz"64 şeklindeki yaklaşım doğru bir yaklaşımdır. Zira sözü edilen bölünme bugünden yarına beklenebileceği gibi, kıyamet sabahına kadar bu sürecin tamamlanmasını beklemek de olasıdır.

\footnotetext{
62 Abdurrazzâk, el-Musannef, 10/156, "Kitabu'l- Lukata", 18675.

${ }^{63}$ Kurtubî İbn Vaddâh, Kitâbun fihi mâ câe fi'l-Bida'i, thk.Abdullah el-Bedr (Riyad: Dâru's-Samî'î, 1961),177 (No. 269); Kurtubî İbn Vaddâh, el-Bida've'n-nehyu anhâ, thk. Amr Abdülmun'im Selîm (Kahire-Cidde: Mektebetu İbn Teymîyye-Mektebetu el-İlm, 1995), 166 (No. 249).

64 İbn Vaddâh, el-Bida've'n-nehyu anhâ, 166 (No. 249).
} 
İlk kez eserini bu rivayet merkezinde kurgulayan Malatî, Yahudi ve Hristiyanların kurtulacakları söylenen fırkalarını ismen zikretmekle sınırl bir biçimde, rivayetin ilk bölümü ile ilgilenmiş görünüyor. ${ }^{65} \mathrm{Bu}$ konuda, sınırlı çaba gösteren diğer sünnî isim ise Şehristânî'dir. ${ }^{66} \mathrm{O}$, el-Milel ve'nNihal'inin başında hem rivayeti ögelerine ayırarak tahlil etmiş, hem de, bu öğelerden olduklarını kabul ettiği Yahudi, Hristiyan ve Mecusilere ek olarak İslam dini mezhep tasniflerine eserinde yer vermiştir. ${ }^{67}$

\section{Mezhep Tarihçilerinin Konuya İlişkin Algıları}

Mezhep tarihçileri özellikle Ehl-i Sünnet çatısını belirlerken fıkhi ayrılıkları tolere etmiş ve ahkâm konusundaki ihtilafları görmezden gelebilmiş görünürler. Bağdadî, ehl-i sünnetin helal ve haramlarda ihtilaf ettiğini, fakat onlar arasında tefsik ve tadlili gerektiren ayrımların bulunmadığına, bu bağlamda dikkat çeker. ${ }^{68}$ Fer'î ahkâma ilişkin ihtilafların İslam ümmeti içerisinde tolere edilmesi, fıkhi mezheplerin daha erken oluşmasına da imkân sağlamış görünüyor. İtikada ilişkin ihtilaflar ise tolere edilmediği için, erken dönem okumalarında itikadi mezheplerden değil bağımsız âlimlerden bahsetmek daha yaygındır. Gaylan ed-Dimeşkî, Ca'd b. Dirhem, Ma'bed el Cuhenî,... bu anlayışın bir yansıması olarak adlarına ekol nispet edilmemiş, bağımsız alimler olarak görülmüşlerdir. ${ }^{69}$ Çünkü gelenek itikâdî ayrışmaya karşı direnç göstermiş, fakat ahkâmdaki ihtilaflara karşı hoşgörülü olmuştur. ${ }^{70}$

Bağdadî söz konusu hadise ilişkin yorumunda; "rivayetin sözünü ettiği ihtilafların, fikhi ihtilaflar olmayıp, inanca ilişkin konularda kurtuluşa erecek firkaya muhalefet edilmesidir" der. ${ }^{71} \mathrm{O}$, Ebu Hanife, Malik, Şâfiî, Evzâî, Sevrî ve Zahiriler gibi fikhi mezhepleri es-sevâdu'l-âzam çatısı altında da ele alarak ${ }^{72} \mathrm{el}$ Fark Beyne'l-Fırak'ı bu rivayetin gölgesinde tasnif eder. Söz konusu ekolleri yetmiş üçe tamamlamak gayretinde olduğunu da kendisi ifade eder. ${ }^{73}$ Bağdadî, eserinde Ravâfid (Şiâ), Havâric, Mürcie, Kaderiyye $\left(M u^{\prime}\right.$ tezile) ve bunların alt kolları olmak üzere dörtlü bir çatı ve ek fırkalardan ${ }^{74}$ oluşan bir tasnife gitmiş ve tasnifinde bu rivayet grubu içinde yer alan birden fazla rivayete yer vermiştir. ${ }^{75}$

Şehristânî de el-Milel ve'n-Nihal'ini iftirâk hadisi ile bağlantılı ve söz konusu rivayet etkisi altında şekillendirmiştir. ${ }^{76}$ Onun kullandığı metin "Mecusiler yetmiş firkaya Yahudiler yetmiş bir firkaya ayrıldılar. Hiristiyanlar da yetmiş iki firkaya ayrildılar Müslümanlar ise yetmiş üç firkaya ayrılacaktır. Bunlardan kurtulacak olan bir tanedir" rivayetidir. Şehristânî' nin metni yorum biçimi İslam geleneğinde varsayılan yargıya oldukça mesafelidir. Buna göre; onun bu rivayetten temel çıkarımı farklı dinlerin kaç fırkaya ayrıldıklarıdır. Müslümanlar açısından farklılaşan bu gruplardan sadece bir tanesinin doğru olacağı ise Sehristânî'ye göre rivayetin konuya ilişkin hükmü değildir. Ona göre bu hüküm, aklın verdiği bir yargıdır. Çünkü ona göre; çelişen iddialardan sadece birinin doğru olması mümkündür. ${ }^{77} \mathrm{Bu}$ durumda, çelişik iki iddianın aynı anda doğru "hak" olabilmesi olası değildir. Ma'kulât'ta tek doğru ilkesinin geçerli olduğunu, bu yüzden de doğrunun karşısında yer alanın yanlış ya da yalan olduğu, onun tarafından ifade edilir. Bu yüzden Şehristânî, yalnızca bir ekolün kurtulacağını vaad eden perspektifi, rivayet metninden değil, aklın ilkelerinden hareketle onaylamış görünüyor. ${ }^{78}$ Onun ortaya koyduğu perspektifte rivayetlerin daha pozitif mesaj içeren varyantı, ma'kul olmadığı için doğru olması mümkün değildir. Ricali açısından illetli olduğu için onun tarafından reddedilmiş değildir. Şehristânî'nin ortaya koyduğu perspektifte, söz konusu rivayet onun böyle düşünmesine ilham vermemiş, aksine o akli çıkarımından doğan düşüncesini bu rivayet ile delillendirmiş, rivayeti ise düşüncesine kanıt getirmiştir. Onun metne ilişkin yaptığı yorum bizi bu konuda cesaretlendiren sebeptir. Bizi bu kanaate ulaştıran bir diğer neden ise onun, eserinde yaygın olan rivayetin yaygın

\footnotetext{
${ }^{65}$ Ebu Hüseyin Malatî, et-Tenbîh ve'r-Red alâ Ehli'l-Ehvâi ve'l-Bida thk. M.Zahid Kevseri (Kahire: Mektebetu'l-Ezheriye, 2007$), 25$.

${ }^{66}$ Şehristânî, el-Milel ve'n-Nihal,.

${ }^{67}$ Şehristânî, el-Milel ve'n-Nihal, $1 / 4$.

${ }^{68}$ Abdülkahir el-Bağdadî, el-Fark Beyne'l-Fırak,39.

${ }^{69}$ Çınar, “İslam Geleneğinde Mezhepleşme Alg1sı ve Mezhep Olgusu”, 43-70.

${ }^{70}$ Abdülkahir el-Bağdadî, el-Fark Beyne'l-Furak, 26, 27.

${ }^{71}$ Abdülkahir el-Bağdadî, el-Fark Beyne'l-Fırak, 27.

${ }^{72}$ Abdülkahir el-Bağdadî, el-Fark Beyne'l-Fırak, 39.

${ }^{73}$ Abdülkahir el-Bağdadî, el-Fark Beyne'l-Fırak, 38, 39.

${ }^{74}$ Bekriyye, Neccariyye, Dırâriyye, Cehmiyye, Kerrâmiyye'den oluşur. bk. Abdülkahir el-Bağdadî, el-Fark Beyne'l-Fırak, 38.

${ }^{75}$ Abdülkahir el-Bağdadî, el-Fark Beyne'l-Fırak, 23-27.

${ }^{76}$ Şehristânî, el-Milel ve'n-Nihal,1/4.

77 Şehristânî, el-Milel ve'n-Nihal, 1/4, 5.

${ }^{78}$ Şehristânî, el-Milel ve'n-Nihal,1/5.
} 
olmayan bir varyantını senedini bile vermeden kullanmış olmasıdır. Bu varyantta Mecusîler de metne dâhil edilmiştir.

İbn Battâ el-Ukberî'nin kaydettiği ilginç bir metin mezhepler tarihinin bu rivayete dayalı olarak nasıl inşa edildiğine ilișkin bir perspektif sunar. Buna göre; Museyyeb b. Vadih es-Sullemî el-Hımsî, "Yusuf el- Esbât'a (ö. 196/811-12) gittim, ona selam verdim ve ona kendisinden hadis dinlemek için gelmediğimi, ondan "... Ümmetim yetmiş ikiye ayrılacak" hadisinin tefsirini sormak üzere geldiğimi söyledim. Ona, "Sözü edilen bu fırkalar kimlerdir" diye sordum. O da bana "bunlar Kaderiye, Şia -ki onlar Rafizilerdir-, Mürcie ve Hariciler olmak üzere dört tanedir, her birinin 18 alt grubu vardır" dedi. ${ }^{79}$ Onun bu hadise ilişkin formülü, önce Malatî sonra da Şehristânî tarafından alanda uygulanmış görünüyor. Kalhâtî de bu dörtlü şablonu aynyla kullanmıştır. ${ }^{80}$ Metnin Kalhâtî́deki varlığı, onun, Şehristânî ile olan etkileşimi ile yorumlanmaya çalışılmıştır. ${ }^{81}$ Elimizde var olduğu haliyle Nâşî elEkber, el-Bağdâdî, el-İsferâyinî gibi müllifler de iftirâk hadisi ile bağlantılı bir şablon oluşturmuş, mezhepleşmeyi bu rivayet ile bağlantılı bir yoruma tabi tutmuşlardır.

Buna göre hicri ikinci yüzyıldaki bu şablonda, Haricîllerin ve Mürcie'nin yaygın olduğu bir zaman dilimi olması açısından anlamlı hatta ma'kuldür. Hatta bu tasnif hicri IV. yüzyılda yaşamış olan Malatî açısından da kısmen ma'kul olsa bile, aynı şablonun VI. Yüzyıl açısından geçerliliği şüphelidir. Şehristânî'nin bu şablonu Yusuf el-Esbât'ın sözünü ettiğim anekdotunun etkisiyle hazırlamış olabileceğini varsaymak için bir fazla nedenimiz var. Çünkü şablon kaba hatlarıyla birebir aynıdır. Öte yandan rivayetlerde mezheplerin alt kollarına ilişkin bir ima ve işarete yer verilmediği halde, bu çatı yapılar ve ayrışan alt kümelerinin hangi gerekçeler ile yoruma dahil edildiği bu anekdot bilinmediği taktirde meçhul kalacaktır. Oysa sözü edilen anekdot, mezhep tarihçilerinin ilham kaynağına ilişkin bir imada bulunabilir. Gerek rivayeti temel alan musannifler, gerekse bunu hesaba katmayan Eş'arî gibi yazarlar, çatı yapılar ve bunların alt kolları şeklindeki algılarını eserlerine net bir biçimde yansıtmışlardır. Bu rivayetin gölgesinde bir tasnif yapanların, sayıyı tamamlamak gailesiyle böyle bir yola başvurdukları varsayılsa bile, tasniflerinde söz konusu rivayetin etkisine yer vermeyen yazarların neden bu yola başvurduklarına ilişkin bu anekdot daha fazla şey söylememize imkan verir.

Elimizde bu gün bulunan müktesebat içerisinde; çalışmalarında söz konusu rivayete ilk defa yer veren mezhep tarihçisinin en-Nâşî el-Ekber olduğu söylenebilir. İftirâk hadisine ilk kez eserinde yer veren en-Nâşî el-Ekber, Mesâilu'l-İmâme'de rivayete isnadı ile birlikte yer verir. Rivayetten hareketle en-Nâşî el-Ekber, mezheplere ilişkin beşli bir tasnif yapacağını ifade eder. Bunlar, Şia, Mürcie, Mutezile, Hariciler ve Haşeviyye'dir. ${ }^{82}$ Fakat eserin ona aidiyeti şüphelidir. Madelung'un kanaati, söz konusu eserin $\mathrm{Ca}^{\prime}$ fer b. Harb'a ait olduğu yönündedir. Onun iddiası doğru ise -ki çok haklı gerekçeleri var- bu durum eseri dolayısıyla rivayeti çok daha önceki bir zaman diliminde aramak gerekecektir. ${ }^{83}$

Daha sonra ise Malatî'nin, et-Tenbîh ve'r-Redd ${ }^{84}$ adlı eserinde rivayetin ele alındığ 1 tespit edilmiştir.

Eş'arî, Mâkâlatu'l-İslamiyyin ve İhtilafu'l-Musallin adlı eserinde bu rivayete yer vermediği gibi eserinde böyle bir şablonu da gözetmez. Onun iftirâk hadisine daha temkinli yaklaşan Mu'tezilî gelenekle olan köken ilişkisi, söz konusu tekfirci dile de kısmen mesafeli olmasını gerektirmiş olmalıdır. Zira onun ehl-i kıblenin ihtilafları sebebiyle tekfir edilemeyeceği algısına sahip olması, söz konusu rivayet ve kavramlara belirli bir mesafede durmasını gerektirmiştir. Eserini şekillendirirken de iftirâk rivayetinin etkisini göz ardı eden bir tasnifte bulunur. Eş'arî'nin mezheplerin ihtilaflarını tekfir sebebi olarak değil, ehl-i kıblenin konuya ilişkin bakış açısı farkı olarak gören perspektifi, tekfirci dilin kaynakları arayışında gözleri bir kez daha kurtuluş teorisi ve iftirâk hadisleri topluluğuna çevirir. Bu bakış açısında her ekol doğrunun bir parçasıdır. Oysa Eşarî geleneğe mensup Şehristânî eserini oluşturan şablonu bu rivayetin mesajları doğrultusunda yapar ve söz konusu ekollerden sadece birinin doğru olma olasılığı varken geriye kalanlar ise yanılgı içerisindedirler anlayışına sahiptir.

\footnotetext{
${ }^{79}$ İbn Batta, el-íbâne el-Kubrâ, 1/377 (No. 277).

${ }^{80}$ Ebu Abdullah Muhammed b. Saîd el-Ezdî Kalhâtî, el-Keşf ve'l-Beyân thk. Seyyide İsmâîl Kâşif (Umman, 1980), 2/323, vd.

${ }^{81}$ Şehristânî'nin mi yoksa Kalhatî'nin mi daha erken olduğu konusunda bir kararsızlığa karşın, taraflar arasında bir etkileşimin olduğu iddia edilmiştir. bk. Kadir Gömbeyaz, “İbâdî Fırak Literatüründe Şehristânî Etkisi”, İslâmî İlimler Dergisi 10/1 (2015), 149168. Gömbeyaz'ın bu makalesinde bir kararsızlık bulunmamaktadır. Ona göre Kalhatî’nin Şehristânı̂’ den yararlandığı nettir.

${ }^{82}$ Ebu'l-Abbas Abdullah b. Şirşir Nâşî el-Ekber, Mesâilu'l-İmâme min Kitâbi'l-Evsât fíl-Makâlât, thk. Josef Van Ess (Beyrut: Dâru'nNeşr \& Frans Steiner, 1971), 20.

83 Wilferd Madelung, “Frühe mu 'tazilitische Häresiographie: das Kitâb al-Ușûl des Ğa 'far b. Ḥarb?”, Der Islam 57/2 (1980), 220236.

${ }^{84}$ Malatî, et-Tenbîh ve'r-Red alâ Ehli'l-Ehvâi ve'l-Bida, 25.
} 
Onun konuya iliş̧in ulaştı̆̆ı ve temel aldığ1 metin; "Mecusiler yetmiş fırkaya, Yahudiler yetmiş bir fırkaya, Hristiyanlar yetmiş iki firkaya ayrıldıkları ve Müslümanların yetmiş üç firkaya ayrllacakları şeklindedir." ${ }^{5}$ Söz konusu rivayet grubunun daha yaygın varyantları varken, onun neden bu varyantı tercih ettiği ise üzerinde düşünülmeyi gerektiren bir konudur. ${ }^{86}$

Öte yandan Şehristânî, birbiri ile çelişen iki şeyin aynı anda doğru olması mümkün görmediği için, birden fazla mezhebin hakkı temsil ediyor olarak cennette olmasına imkân vermeyen teziyle alana zihinsel bir katkı sağlar. Bu yaklaşımının gereği olarak o, tek fırkanın kurtuluşunu öngören rivayeti sıhhati sebebiyle değil, akla uygun olduğu düşüncesiyle tercih etmiş görünür. Eserin başında zikrettiği varyantın gelenekte yaygın olmaması biryana, o metnin isnadını zikretme gereği duymadan aktarmıştır. Bu durum onun metin merkezli bir yargıyı değil sözünü ettiğimiz zihinsel çıkarımı ve aklî yargıyı merkeze alıp, söz konusu rivayeti ise destekleyici unsur olarak gördügü varsayılabilir. Onun İslam geleneğinde izine rastlanılmayan bu yaklaşımı, İslam kültür geleneğinde bir alternatif alg1 olarak gündeme gelmiş ve savunulmuştur. ${ }^{87}$ Buna karşın Gazzâlî, Faysalu't-tefrika' da birbirine zit anlayışları barındıran rivayetler topluluğunun birlikte ele alınması gerektiğini öneren yaklaşımı ile alandaki tekfirci, ötekileştirici dili belirli limitlerde tutmak çabasındadır. ${ }^{88}$ Fakat kendisinden sonraki söylemlere bakıldığında onun, bu önerisinde inandırıcı olamadığı dolayısıyla görüşüne taraftar bulamadığı söylenebilir. El-Fırkatu'n-Nâciye anlayışı karşısında bir umut ışığı olarak ortaya çıkan ve Kerramî geleneğin de istidlalde bulunulduğu pozitif mesaj içeren varyantın, neden tercih edilemeyeceğine ilişkin akli gerekçe Şehristânî tarafından ortaya konulmuştur. Konuya ilişkin rical tenkitçilerinin söz konusu rivayetin senedine yaptıkları eleştiriler sebebiyle bu aktarım, iftirâk hadisi olarak bilinen rivayete bir alternatif olmayı başaramamıştır.

Kalhâtî de eserine bu rivayet ekseninde şekil vermiş bir diğer âlim olup, o, rivayette sözü edilen dinlere yer verirken, her defasinda söz konusu rivayeti tekrar ederek, bu dinlere eserinde yer verir. Onun bu sunumu, eserinde söz konusu dinlere neden yer verdiğine ilişkin bir kanaat verme amacı taşır. O, bu tavrı ile mezhepler tarihi yazıcılığı açısından göreceli olarak çağdaşlarından daha ileri bir noktadır. ${ }^{89}$ Zira onun bu çabası rivayeti söz konusu dinler üzerinden doğrulama anlamı taşır.

İsferâyînî de eserini bu rivayete göre şekillendirmiş ve rivayete eserinde yer vermiştir. $\mathrm{O}$, ana fırkaları ve onların alt kollarını kısaca açıklarken, fırka-i nâciye olan yetmiş üçüncü fırkanın ise "Ashâbu'l-hadîs ve Ashabu'r-Re'y'den oluşan "Ehlu's-Sunne ve'l-Cemâ'a" olduğunu söyler. ${ }^{90}$

Mu'tezile'den Kâdî Abdulcebbâr ise bu rivayete ilişkin olarak cemâ'a kavramına ilişkin kendi yorumunu yaparak katkı sağlar. Buna göre; “cemâ’at'tan kasıt bir şey üzerinde uzlaşmaktır" bu ise icmâ ile olur. Fakat eğer bir şey üzerinde uzlaşmadan söz edilemiyor ise cemấate sarılmak gerekmez der.91 O, cemâ'at algisına, İbn Mesud'tan aktarılan "cemấat, Allah'a itaate muvafik olandır, bu bir kişi olsa bile, [hak kimde ise] cemâ'at odur" şeklindeki rivayeti delil getirir. ${ }^{92}$ Ona göre, batıla tabi ise kalabalık olsa bile cemâ'at değildir. Öte yandan; hakikat üzere olduktan sonra, azınlıkta olsa bile o cemâ'at'tir ${ }^{93}$ algısında, gelenekte kabul görmeyen dolayısıyla sınırlı sayıda temsilcisi bulunan İbn Mesud'un anlayışını benimser.

Kâdî, ayetlerde hak üzere olduğu için medh edilenleri şahid getirerek, asıl olanın kişinin kalabalık içinde olması değil, doğruya nispetle bireyin nerede durduğudur. ${ }^{94}$ Peygamber ortaya çıktığında tek

\footnotetext{
${ }^{85}$ Şehristânî, el-Milel ve'n-Nihal, $1 / 4$.

${ }^{86} \mathrm{Bu}$ varyant Harici- İbadî gelenekte de kullanılmış bir varyanttır. bk. Kalhâtî, el-Keşf ve'l-Beyân, 2/265, 323.

${ }^{87}$ Makdisî, Ahsenü't- Tekâsîm fì Ma'rifeti'l-Ekâlîm, 39.

${ }^{88}$ Ebu Hamid Gazzâlî, Faysalu’t Tefrikâ nşr. Mahmud Bîcû (Dimeşk,y.y. 1993); Gömbeyaz, Kadir, and Sadiye Seymen ." '73 Fırka Hadisi “Allah’ın Geniş Rahmetini Daraltır” mı? Gazzâlı’’nin Faysalu't-tefrika'daki 73 Fırka Hadisine Yaklaşımı Üzerine Bir Analiz.'”, Tevilat 1/2 (2020), 335-348.
}

${ }^{89}$ Kalhâtî söz konusu rivayet etkisiyle eserini şekillendirmiş, o da eserinde kullandığı rivayette sözü geçen (Mecusi, Yahudi, Hristiyan) dinlerin mezheplerine ilişkin incelemelere yer vermiştir. Rivayetin kullandığı versiyonunu bu dinlerin her birine ilişkin bölümün başında rivayeti tekrar ederek, bu dinlere hangi sebepten eserinde yer verdiğinin gerekçesini söyler. bk. Kalhâtî, el-Keşf ve'l-Beyân,2/265, vd.

${ }^{90}$ İsferâyînî, et-Tabsir fi'd-Din ve't- temyizu'l- Fırkate'n-Nâciyete ani'l- Firaki'l- Hâlikin, 15-17.

${ }^{91}$ Kâdî Abdulcebbâr, "Kitab Fadlu'1-İtizal ve Tabakâtu'l-Mu'tezile ve Mubayenetihim li- Saîri'l- Muhalifin", 146.

${ }^{92}$ Kâdî Abdulcebbâr, “Kitab Fadlu'l-İtizal , 147.

${ }^{93}$ Kâdî Abdulcebbâr, “Kitab Fadlu'l-İtizal, 147.

${ }^{94}$ Kâdî Abdulcebbâr, "Kitab Fadlu'l-İtizal, 148. 
kişi olarak azınlıktadır fakat hak üzeredir, buna karşın müşrikler kalabalık olmalarına karşın batıl üzereydiler diyerek, o kalabalık olmanın hakikat üzere olmayı garanti etmediğine vurgu yapar. ${ }^{95} \mathrm{Bu}$ yaklaşımı ile Kâdî'nin hem es-sevâdu'l-ấzam hem de cemâ'at kavramına yeni bir yorum getirdiği söylenebilir. ${ }^{96}$ İftirâk hadisinin söz konusu meşhur varyantını ise Kâdî yorumlayarak kullanır.97

Yaygın metinlerin, yaygın varyantlarında metnin ana gövdesi "İsrail oğulları.... ayrıldılar" yargısı, söz konusu rivayetler topluluğunun ilk yargısıdır. "Benim ümmetim de.... ayrılacaktır" metne ilişkin ikinci yargıdır. "Bu ayrılacakların biri hariç ötekiler cehennemdedir. Kurtuluşa erecek olanlar,...dır" yargısı ise metindeki üçüncü yargı ifadesidir. İkinci ve üçüncü yargı geleceği referans aldığı için kıyamet gününe kadar önü açık bir süreçtir. "Biri hariç diğgrleri cehennemdedir" ifadesi metindeki hüküm ve belirleyici yargıdır. Ve bu rivayete ilişkin hiçbir olgu doğrulanmamış olduğu halde, doğru varsayılarak koca bir gelenek bu varsayıma göre tasnif edilmiştir. Zira şayet "biri hariç diğerleri cehennemdedir" ifadesi metinde yer almasaydı, muhtemelen ekoller arasında bir tekfir dili oluşmayacak, kurtuluş fırkası iddiası dillendirilemeyecekti. Böylece ötekileştirici bir dil de alanda muhtemelen hâkim olmayacaktı. Zira el-fıraku'd-dâlle (sapık fırka) anlayışı bu algının bir sonucu olarak alanda yerleşmiş, el-firkatu'n-nâciye anlayışı da eş zamanlı var olmuştur. Bu durumda bizim izini sürdügümüz şey, rivayetin mi yoksa algının mı önce olduğu değil, metnin bu anlayışın ortaya çıkmasında ya da var ise bile yerleşmesindeki muhtemel rolüdür. Oluşan tabloda bu aktarımların belirleyici etkisi sosyal algıya da şekil kazandırmıştır. Davranışların ardınki öncüllerin tespiti yapılmaksızın rahatsızlık duyulan davranış kalıplarının değiştirilmesine imkân yoktur. Davranış kuramcıları davranış değişikliğinin ancak söz konusu davranışa kaynaklık eden yargının değiştirilmesiyle mümkün olduğunu varsayar. Bu durumda kendisine karşı savaşılacak şey davranış değil, öğretidir.

Son olarak; söz konusu rivayetin literatürde tespit edilmiş en erken örneklerinin, üçüncü yüzyılın ortaları olduğu, tespit edilmiştir. ${ }^{98}$ Ehl-i Hadis, fırkalaşma olgusuna ${ }^{99}$ ve iftirâk hadisine Kitâbu'l-iman tarzı eserlerinde yer vermediği gibi hicri üçüncü yüzyıldan itibaren yazılmaya başlanan Kitâbu'sSünne gibi akaide ilişkin eserlerinde de yer almaz. Bu eserlerde, konuya ve rivayete ilgi gösterilmediği söylenmiştir. ${ }^{100}$ Fakat hicri dördüncü yüzyılın ilk yarısında, ekoller arasındaki çekişme ve reddiye geleneğinin bir parçası olarak, Şerhu's-Sünne türü eserlere yansıdığı ve alanda yaygınlaştığı tespit edilmiştir. ${ }^{101} \mathrm{Bu}$ tarihten sonra da söz konusu rivayetin şekillendirdiği bir algı ile İslam mezhepleri bu rivayet topluluğunun sunduğu imkânlarla tematik ve şematik tasniflere tabi tutulmuştur.

\section{SONUÇ}

İslam mezhepleri geleneği içerisinde doğru tek parça değildir ve benim görüşüm de doğrunun bir parçasıdır şeklindeki yapı, "içtihad, içtihadı nakzetmez" anlayışının alana yansımasıdır. Düşüncenin bu evresinde tek doğrucu bir algının alana hâkim olduğundan söz edilemez. Sürece eklemlenmek isteyen yapıların yarışmacı bir ruh ile "benim görüşüm daha doğrudur" anlayışları, bir ötekileştirme sürecinin alanda başladığını haber verir. Bu algı ekollerin kendi aralarında bir mukayeseye girdiklerini gösterir. "Benim anlayışım en doğrudur" şeklindeki iddialı söylemin alana dâhil olduğu süreçte bile alanda başka aktörlerin varlığını onaylayan bir zihin durumunun varlığından söz edilebilir. Fakat "benim görüşüm tek doğrudur, diğerleri yanlıştır" algısı, tekelci ve ötekileri dışlayan bir anlayışın temsilcisidir ve bu algıyı kurtuluş fırkası ve kurtuluş doktrini fikri beslemiş görünmektedir.

Sürecin bu evresinden sonra, tek doğrucu bir anlayışın alana hâkim olduğundan söz edilebilir. Genel bir kanaat olarak "ehl-i kıble tekfir edilemez" anlayışına kısmen mesafeli bir anlayışı temsil eden "benim görüşüm tek doğrudur" ekseninde kümelenen tek doğrucu marjinal anlayışın, diğer tüm söylemleri yok saydığı hatta süpürdüğü söylenebilir. Bu zihin durumu, geleneğin ev sahibi statüsündeki "ehl-i hadis" tarafından yoğun bir biçimde kullanılmıştır. Algının alana yansıması

\footnotetext{
${ }^{95}$ Kâdî Abdulcebbâr, “Kitab Fadlu'l-İtizal, 148.

${ }^{96}$ Kâdî Abdulcebbâr, “Kitab Fadlu'l-İtizal, 148, 149.

${ }^{97}$ Kâdî Abdulcebbâr, “Kitab Fadlu'l-İtizal, 146.

${ }_{98}$ Muhammet Emin Eren, Hadis Tarih ve Yorum: 73 Fırka Hadisi Üzerine Bir Inceleme, 114, 115.

${ }_{99}$ Kasım b. Sellâm, Kitabu'l-İman adlı eserinde fırkaların İman algıları ekseninde fırkalaşmaya atıflar yapar. Burada bizim dikkatlere sunmak istediğimiz husus, bunun Ashâbu'l- hadis arasında bu dönemde yaygın bir tutum olmadığıdır. Bu asla "hiç" anlamı taşımaz. bk. Bayram Çınar, "Bir Süreç Olarak İman: Ebu Ubeyd Kasım b. Sellam'ın İman Değerlendirmesi”, Akademik Platform İslami Araştırmalar Dergisi 4/3 (2020), 345-369.

100 Eren, Hadis Tarih ve Yorum: 73 Firka Hadisi Üzerine Bir İnceleme,114, 115.

${ }^{101}$ Ebu Muhammed Berbehârî, Şerhu's-Sunne, thk. Hâlid b. Kâsım er-Radâdî (Riyad: Dâru's-Selef, 2000),89 (No. 95).
} 
Hanbeli gelenek tarafından kullanılan "ehl-i sünnet-i Hâssâ" ifadesi ile kavramsallaştırılmıştır. Bu dini yaklaşım "yalnız ben doğruyum" anlayışının inşa ettiği bir zeminde, "el-firaku'd-dâlle" ve "el-firkatu'nnâciye" şeklindeki düalist zihni üretmiştir. Gelinen noktada "hak-batıl" mezhep algisı, Müslüman geleneğin konuya ilişkin temel parametrelerinden biridir ve bu yaklaşım var olanların biri hariç, ötekilerinin tümünü sapkın ilan eder. Bu sosyal zeminde, iddia sahiplerinden biri sahih olarak onay görmü̈s, ötekiler ise olgusal olarak batıl ilan edilmişlerdir.

Daha geniş çatı kavramlar ve daha tolere eden anlayışlar geliştirilemediği takdirde el-fırkatu'nnâciye'den ayrılmamak adına fikri çoraklaşma taklit maskesi altında dindarlıkları kemirerek, bireyin dindarlık şuurunu yok edecektir.

Bir yanıla "ihtilâfu ummetî rahmetun" diyerek fikir zenginliğini teşvik eden Hz. Peygamber'in tutarsız mesajlar verdiği varsayılamayacağı için, İslam geleneğinde iftirâk ve ihtilaf ayrımının daha net yapılması gerekmiştir. Bu durumda ise her ihtilaf, bir ayrışmayı gerektirmez, ihtilaf eden her yapı sapkın olarak görülemez anlayışını doğurmuştur.

Özellikle negatif mesaj sunan ve gelenekte şöhretli olan iftirâk hadisi varyantının üstlendiği misyon birlikte yaşama projesinin bir kader olduğu algısını sunarak, birlikte yaşama stratejisine muhalefet etmenin dini bir sapkınlık olduğu şeklinde bir zihin inşa etmiştir. Bu yaklaşımla oluşturulan algıda ya biri ya da öteki doğrunun temsilcisidir. Doğası itibarıyla fütürolojik bir değerlendirme ifade eden metin, anlam itibarıyla fiten ve melâhim edebiyatının konusudur. Geleceğe ilişkin sayısal bir değerlendirme sunduğu için verili olan bu metin, İslam fırâk geleneğinin yazarlarında cebri ve kaderci bir algıya da kaynaklık etmiştir. "Resulullah haber verdi ise olacaktır bize düşen de oluşan tablonun kaydın tutmaktır" şeklinde bir tavrı sonuç verdiği gibi, bu algının doğurduğu zihinsel zorlamalar ile bir tablo inşa etme eğilimini de ortaya çıkarmıştır. Sunduğu nihai perspektif sebebiyle ayrışmaları derinleştiren ve tarafların bir daha bir araya gelmelerine olanak vermeyen kurgusu sebebiyle, söz konusu rivayet, hem kaosu besleyen hem de meşrulaştıran çift kutuplu bir görev ifa etmiştir. Olanı, önü alınamaz; dolayısıyla mukadder algısı içinde sunan metnin kurgusu, insanı da müdahaleleri ile durumunu belirleyen pozisyonundan çıkararak, olacak olana seyirci pozisyonuna indirgemiştir.

Söz konusu negatif (biri hariç hepsi ateştedir) mesaj taşıyan rivayetin dışlayıcı etkisi sebebiyle her ekol bu hadisten hareketle yalnızca kendilerinin es-sırâtu'l-mustakîm denilen doğru yol üzere oldukları iddiasında bulunmuşlardır. Tek doğrucu bir algıyı himaye eden rivayet, ihtilafları düşüncenin farklı tonları olarak görmek, doğrudan payı olan paydaşlar olarak göstermek yerine, ortak paydaları olmayan, rekabet halindeki yapılar olarak görmüş ve bir araya gelmez çelişik anlayışlar olduğu algısını alana pompalamıştır.

\section{KAYNAKÇA}

'İvecî, Galib b. Ali. Fıraku Muassira tentesib ile'l- İslam ve beyanu mefkifu'l- İslam minha. 3 Cilt. Cidde: Mektebetu'l-Asriyye ez-Zehebiye, 2001.

Abdülkahir el-Bağdadî. el-Fark Beyne'l-Fırak thk. Osman el-Huşî. Beyrut: Dâru'l-âfâk el-Cedide, 1977.

Abdurrazzâk, Ebu Bekr Abdurrazzâk b. Hemmâm es-San'ânî. el-Musannef thk. Habiburrahman elA'zmî. 11 Cilt. Beyrut: el-Mektebetu'l-İslamî, 1983.

Âcurrî, Ebu Bekr Muhammed b. el-Huseyn. Kitâbu'ş-Şerî‘a, thk. Abdullah b. Ömer ed-Dumeycî. 5 Cilt. Riyad: Dâru'l-Vatan, 1997.

Ahmet b. Hanbel. el-Müsned thk. Ahmed Muhammed Şâkir. 8 Cilt. Kahire: Dâru'l-Hadis, 1995.

Berbehârî, Ebu Muhammed. Şerhu's-Sunne, thk. Hâlid b. Kâsım er-Radâdî. Medine: Mektebetu'1Ğurebâi'l-Eseriyyye, 1993.

Ebu Dâvûd, Suleyman b. Eş'âs b. İshak es-Sicistânî. es-Sunen thk. Muhyiddin Abdulhamid. 4 Cilt. Beyrut: Mektebetu'l-'Asriye, ts.

Ebu Kerim, Muhammed. Vasıtıyyetu Ehli's-Sunne Beyne'l- Fırak. b.y.:Dâru'r-Râye, 1994.

Ebu Ya'lâ, el-Mavsılî. el-Musned thk. Huseyn Selim Esed. 13 Cilt. Dimeşk: Dâru'l-Me'mûn li't-Turâs, 1984.

Beyhakî, Ebu Bekr Ahmed b. el-Huseyn b. Ali. es-Sunenu'l-Kubrâ. thk. M. Abdulkâdir Atâ. Beyrut: Dâru'l-Kutubi'l- İlmiyye, 2003.

Curkânî, Hüseyin bin İbrahim Ebu Abdullah el-Hamzânî. el-Ebâtil ve'l-Menâkîr ve's-Sihâh ve'l-Meşâhir thk. Abdulcebbâr Ferîvaî. 2 Cilt. Riyad: Dâru's-Samî'i, 2002. 
Çınar, Bayram. "Bir Süreç Olarak İman: Ebu Ubeyd Kasım B. Sellam'ın İman Değerlendirmesi". Akademik Platform İslami Araştırmalar Dergisi 4/3 (2020), 345-369.

Çınar, Bayram. "İslam Geleneğinde Mezhepleşme Algısı ve Mezhep Olgusu”. Akademik-Us 4/2 (2020), 43-70.

Eren, Muhammet Emin. Hadis Tarih ve Yorum: 73 Fırka Hadisi Üzerine Bir İnceleme. İstanbul: Kuramer Yayınları, 2017.

Eren, Muhammet Emin. “İftirak Hadisinin Anlaşılma Biçimleri Üzerine”. Ankara Ünivesitesi İlahiyat Fakültesi Dergisi 55/2 (2014), 59-97.

Gazzâlî, Ebu Hamid. Faysalu’t Tefrikâ nşr. Mahmud Bîcû. Dimeşk,y.y. 1993.

Gömbeyaz, Kadir. "73 Fırka Hadisinin Mezhepler Tarihi Kaynaklarında Fırkaların Tasnifine Etkisi”. Uludă̆ Üniversitesi İlahiyat Fakültesi Dergisi 14/2 (2005), 147-160.

Gömbeyaz, Kadir. "İbâdî Fırak Literatüründe Şehristânî Etkisi”. İslâmî Illimler Dergisi 10/1 (2015).

Gömbeyaz, Kadir, Seymen, Sadiye."73 Fırka Hadisi "Allah'ın Geniş Rahmetini Daraltır" mı? Gazzâlî’nin Faysalu't-tefrika'daki 73 Fırka Hadisine Yaklaşımı Üzerine Bir Analiz.'" Tevilat 1/2 (2020), 335-348.

Hâkim en-Nîsâbûrî, Ebu Abdillâh . el-Mustedrek ale's-Sahihayn thk. Mustafa Abdulkadir Atâ. 4 Cilt. Beyrut: Dâru'1 Kutubu'l-İlmiye, 1990.

Herevî, Abdullah b. Muhammed b. Ali . Zemmu'l-Kelam ve Ehlihi. 5 Cilt. Medine: Mektebetu'lĞurebâi'l-Eseriyyye, 1998.

İbn Hibbân. Sahîhu İbn Hibbân thk. Şuayb el-Arnavûd. 18 Cilt. Beyrut: Müessesetü'r-Risâle, 1993.

İbn Abdirabbih, Şihâbuddin Ahmed b. Muhammed el-Endulûsî. el-ikkdu'l-Ferîd. Beyrut: Dâru'lKutubi'l-i̇lmiyye, 1404.

İbn Batta, Ebû Abdullah Ubeydullah b. Muhammed el-Ukberî. el-İbâne el-Kubrâ thk. Rıdâ el- Mu'tî vd. 9 Cilt. Riyad: Dâru'r-Râye, 1994.

İbn Ebî Asım, Ebu Bekr. es-sünne thk. Nâsruddin el- Albanî. 2 Cilt. Beyrut: el-Mektebetu'1- İslamiye, 1400.

İbn Hacer, el-Askâlanî. Fethu'l- Bârî thk. Abdu'l- Aziz b. Abdullah b. Bâz. 13 Cilt. Beyrut: Dâru'lMearife, 1379.

İbn Vaddâh, El-Kurtubî. el-Bida've'n-nehyu anhâ thk. Amr Abdülmun'im Selîm. Kahire-Cidde: Mektebetu İbn Teymîyye-Mektebetu el-ïlm, 1995.

İbn Vaddâh, El-Kurtubî. Kitâbun fihi mâ câe fi'l-Bida'i thk. Abdullah el-Bedr. Riyad: Dâru's-Samî'î, 19961.

İsferâyînî, Ebu'l-Muzaffer. et-Tabsir fi'd-Din ve't- temyizu'l-Fırkate'n-Nâciyete ani'l-Fıraki'l- Hâlikin thk. Kemal Yusuf el-Hut. Beyrut: Alemu'l-Kutub, 1983.

Kâdî Abdulcebbâr, Ebu'1-Hasen b. Ahmed el-Hemedanî. “Kitab Fadlu'1-İtizal ve Tabakâtu'l-Mu'tezile ve Mubayenetihim li- Saîri'l- Muhalifin". Ebu'l-Kasım Belhî, ,Kâdî Abdülcebbar, Hâkim el-Cüşemî, Kitab Fadlu'l-İtizal ve Tabakâtu'l-Mu'tezile thk.Fuâd Seyyid. 148,149. Beyrut: Dâru'l- Fârâbî, 2017.

Kalhâtî, Ebu Abdullah Muhammed b. Saîd el-Ezdî. el-Keşf ve'l-Beyân thk. Seyyide İsmâîl Kâşif. 2 Cilt. Umman, 1980.

Kanter, Özden. "Kurtuluşa Eren Fırka/el-Fırkatu'n-Nâciyye İnancı". Hitit Üniversitesi İlahiyat Fakültesi Dergisi 16/31 (2017), 29-46.

Keleş, Ahmet. “73 Furka Hadisi Üzerine Bir İnceleme”. Marife 5/3 (2005), 25-45.

Kubat, Mehmet. "73 Firka Hadisi'ni Yeniden Düşünmek". İnönü Üniversitesi İlahiyat Fakültesi Dergisi 3/2 (2012), 9-45.

Lâlekâî, Hasan b. Mensur el-. Şerh Usuli I'tikad thk. Sa'd el Gâmidî. 4 Cilt. Sudi Arabistan: Dâru Taybe, 2003.

Madelung, Wilferd. "Frühe mu'tazilitische Häresiographie: das Kitâb al-Ușâl des Ğa 'far b. Harb?" Der Islam 57/2 (1980), 220-236.

Makdisî, Muhammed b. Ahmed. Ahsenü't- Tekâsîm fî Ma'rifeti'l-Ekâlîm ed. M.J. De Goeje. Leiden: y.y., 1906. 
Malatî, Ebu Hüseyin. et-Tenbîh ve'r-Red alâ Ehli'l-Ehvâi ve'l-Bida thk. M.Zahid Kevseri. Kahire: Mektebetu'l-Ezheriye li't-Turas, 2007.

Mervezî, Nasr b. Haccac. es-Sunne thk. Sâlim Ahmed es-Selefî. Beyrut: Muessestu'l-Kutubu's-Sekafiye, 1408.

Nâşî el-Ekber, Ebu'l-Abbas Abdullah b. Şirşir. Mesâilu'l-İmâme min Kitâbi'l-Evsât fíl-Makâlât thk. Josef Van Ess. Beyrut: Dâru'n-Neşr Frans Ştâiner, 1971.

Nesefî, Ebu Mutî'. Kitâbu'r-Redd 'ale'l-Bida' nşr. Marie Bernand. Kahire: y.y., 1980.

Oral, Osman. "73 Fırka Hadisinin Kelâm İlmi Açısından Değerlendirilmesi". Kelam Araştırmaları Dergisi 12/2 (2014), 295-313.

Şâtibî, Ebu İshâk. el-I'tisâm thk. Selim b. 'İyd el-Hilalî. 2 Cilt. Su'di Arabistan: Dâr ibn Affân, 1992.

Şâtibî, Ebu İshâk. el-Muvâfakât thk. Ebu Ubeyde Meşhur. 7 Cilt. Su'di Arabistan: Dâr ibn Affân, 1997.

Şehristânî, Ebu'l-Feth Muhammed Abdulkerim. el-Milel ve'n-Nihal thk. Ahmed Fehmi Muhammed. 3 Cilt. Beyrut: Dâru'1 Kutubu'l-i̇lmiye, 1992.

Taberânî, Ebu'l-Kâsım Suleyman b. Ahmed b. Eyyûb. el-Mu'cemu'l-Kebîr thk. Hamdi b. Abdulmecîd es-Selefî. 25 Cilt. Kahire: Mektebetu İbn Teymîyye, 1994.

Tirmizî, Muhammed b. İsa. el-Câmi'u'l-Kebîr (Sunenu't-Tirmizî) thk. Beşşâr Avvâd Mahfûz. 6 Cilt. Beyrut: Dâru'l- Garb el- İslamî, 1998.

Yurtalan, Betül. “Bir Coğrafyacının Gözünden Mezhepler: el-Maḳdisī’nin Aḥsenu't-Teḳāsīm'inde Mezhepler Bahsinin Tahlili". Ankara Üniversitesi İlahiyat Fakültesi Dergisi 62/ (2021), 135-168. 